\title{
49. MIDDLE EOCENE TO OLIGOCENE PLANKTONIC DIATOM STRATIGRAPHY FROM DEEP SEA DRILLING SITES IN THE SOUTH ATLANTIC, EQUATORIAL PACIFIC, AND INDIAN OCEANS ${ }^{2}$
}

\author{
Juliane Fenner, Geologisch-Paläontologisches Institut der Universität Kiel, Olshausenstrasse 40-60, D 2300, \\ Kiel, Federal Republic of Germany
}

\begin{abstract}
The relative abundance of Paleogene diatom species was determined at DSDP Sites 356 and 357 (southwest Atlantic), 64, 65, 69, 71A, 72, 73, 77B, 161, 163, 167, 289, and 292 in the equatorial Pacific, and 216, 217, and 220 in the Indian Ocean. Biostratigraphy and paleoceanographic implications of the differences in assemblage compositions are discussed.

The assemblage analysis for the middle and late Eocene at Sites 356 and 357 in the mid-latitude southwest Atlantic provides insight into the paleolatitudinal distribution of diatom species.

In the middle Eocene the diatom assemblages at these sites are composed of low-latitude and cosmopolitan species, whereas during the late Oligocene high-latitude species are present, reflecting an extension toward the equator of the circum-Antarctic assemblage that can be related to climatic cooling and probably intensified meridional wind and surface water circulation.

In addition, the Eocene-Oligocene planktonic diatom zonation developed in the low-latitude Atlantic and the Caribbean (Fenner, in press) is tested against the moderately to well-preserved early Oligocene diatom assemblages of the Pacific sites (except for Site 292, at which preservation of diatoms was too poor), and those of middle and late Eocene age at DSDP Site 167. The age assignments obtained by applying this stratigraphic zonation are in accordance with those obtained using other planktonic microfossil groups, thus proving the applicability of this zonation.

The wide occurrence of the same species through the equatorial Atlantic and Pacific oceans and the identical sequence of first appearances have both to be seen as a result of the homogenizing effect of unobstructed circum-equatorial circulation in Tethys.

In the diatomaceous Eocene-Oligocene section of Site 167 in the equatorial Pacific, the change in assemblage composition toward an assemblage dominated by Cestodiscus spp. in the early Oligocene occurs at about the Eocene/Oligocene boundary, as it also does at DSDP Site 366 in the equatorial Atlantic. The value of this change in assemblage composition as a paleoclimatic indicator and stratigraphic marker is suggested.

The only Indian Ocean sites (Sites 216, 217, 220) which contain Eocene-Oligocene diatoms were located just south of the equator during the Eocene. But preservation of diatoms is too poor to allow stratigraphic assignments or to discuss assemblage compositions in relation to other known sections.
\end{abstract}

\section{INTRODUCTION}

Stratigraphic zonation of the Paleogene using planktonic diatoms has been substantially developed during the last ten years. Continuing a long tradition of Russian work on Paleogene diatomaceous deposits, Jousé $(1973,1979)$ compiled information on the stratigraphic occurrences of Paleogene planktonic diatom species from land outcroppings and deep sea cores. Much new information has also been obtained, especially from diatomaceous sections drilled by Glomar Challenger. Dzinoridze et al. (1976, 1979) and Fenner, in Schrader and Fenner (1976), developed a stratigraphic scheme for the Paleogene of the Norwegian Sea. For the low latitudes, Fenner (1982; in press) described ranges of planktonic diatom species through the Eocene and Oligocene from DSDP Sites 13, 366, 366A, and 369A off Northwest Africa and Site 149 in the Venezuela Basin; planktonic diatom zones were also established. For the late Eocene and Oligocene of the circum-Antarctic, Fenner (in press)

\footnotetext{
${ }^{1}$ Hay, W. W., Sibuet, J.-C., et al., Init. Repts. DSDP, 75: Washington (U.S. Govt. Printing Office).

2 Moore, T. C., Rabinowitz, P. D., et al., Init. Repts. DSDP, 74: Washington (U.S. Govt. Printing Office),
}

defined diatom zones, revising older zonal definitions proposed by McCollum (1975), Schrader (1976), Gombos (1977), Weaver and Gombos (1981), and Gombos and Ciesielski (1983).

All the results presented here are from DSDP sites not previously analyzed for Paleogene diatoms; they provide basic new stratigraphic data and an opportunity to test zonations proposed earlier. Site locations appear in Table 1 and Figure 1.

The planktonic diatom zonation used in this study is that defined by Fenner (in press). Zones are defined and correlated to the calcareous microfossil zones in Figure 2.

This study presents part of the data analyzed for a study of Eocene-Oligocene paleoceanography being undertaken jointly with other authors (B. H. Corliss, L. D. Keigwin, Jr., G. Keller, M.-P. Aubry, and W. A. Berggren). The sites were selected to give information on the paleogeographic distribution of species and changes in assemblage composition from the middle Eocene through early Oligocene.

\section{METHODS}

All samples were prepared by boiling the sediment for $10 \mathrm{~min}$. in an equal mixture of $10 \% \mathrm{HCl}$ and $30 \% \mathrm{H}_{2} \mathrm{O}_{2}$ in order to dissolve the calcium carbonate and oxidize the organic matter. Clay minerals were 
Table 1. Present geographic location of the DSDP sites examined.

\begin{tabular}{|c|c|c|c|c|}
\hline Site & $\begin{array}{l}\text { Geographic } \\
\text { Location }\end{array}$ & Latitude & Longitude & $\begin{array}{c}\text { Water } \\
\text { Depth } \\
\text { (m) }\end{array}$ \\
\hline $64,64.1$ & Ontong-Java Plateau & $01^{\circ} 44,56^{\prime} \mathrm{N}$ & $158^{\circ} 36,51^{\prime} \mathrm{E}$ & 2052 \\
\hline $65,65.1)$ & & $04^{\circ} 21,21^{\prime} \mathrm{N}$ & $176^{\circ} 59,16^{\prime} \mathrm{E}$ & 6130 \\
\hline $69,69 \mathrm{~A}$ & & $06^{\circ} 00,00^{\prime} \mathrm{N}$ & $152^{\circ} 51,93^{\prime} \mathrm{W}$ & 4978 \\
\hline $71 \mathrm{~A}$ & & $04^{\circ} 28,28^{\prime} \mathrm{N}$ & $140^{\circ} 18,91^{\prime} \mathrm{W}$ & 4419 \\
\hline 72 & & $00^{\circ} 26,49^{\prime} \mathrm{N}$ & $138^{\circ} 52,02^{\prime} \mathrm{W}$ & 4326 \\
\hline 73 & Central equatorial Pacific & $01^{\circ} 54,58^{\prime} \mathrm{S}$ & $137^{\circ} 28,12^{\prime} \mathrm{W}$ & 4387 \\
\hline $77 \mathrm{~B}$ & & $00^{\circ} 28,90^{\prime} \mathrm{N}$ & $133^{\circ} 13,70^{\prime} \mathrm{W}$ & 4291 \\
\hline $161 \mathrm{~A}$ & & $10^{\circ} 14,25^{\prime} \mathrm{N}$ & $139^{\circ} 57,21^{\prime} \mathrm{W}$ & 4939 \\
\hline 163 & & $11^{\circ} 14,66^{\prime} \mathrm{N}$ & $150^{\circ} 17,52^{\prime} \mathrm{W}$ & 5230 \\
\hline 167 & & $07^{\circ} 04,10^{\prime} \mathrm{N}$ & $176^{\circ} 49,05^{\prime} \mathrm{W}$ & 3176 \\
\hline 216 & Ninetyeast Ridge & $01^{\circ} 27,73^{\prime} \mathrm{N}$ & $90^{\circ} 12,48^{\prime} \mathrm{E}$ & 2262 \\
\hline 217 & Ninetyeast Ridge & $08^{\circ} 55,57^{\prime} \mathrm{N}$ & $90^{\circ} 32,33^{\prime} \mathrm{E}$ & 3030 \\
\hline 220 & Southeast Arabian Basin & $06^{\circ} 30,97^{\prime} \mathrm{N}$ & $70^{\circ} 59,02^{\prime} \mathrm{E}$ & 4036 \\
\hline 289 & Ontong-Java Plateau & $00^{\circ} 29,92^{\prime} \mathrm{S}$ & $158^{\circ} 30,69^{\prime} \mathrm{E}$ & 2206 \\
\hline 292 & Benham Rise & $15^{\circ} 49,11^{\prime} \mathrm{N}$ & $124^{\circ} 39,05^{\prime} \mathrm{E}$ & 2943 \\
\hline 356 & São Paulo Plateau & $28^{\circ} 17,22^{\prime} \mathrm{S}$ & $41^{\circ} 05,28^{\prime} \mathrm{W}$ & 3203 \\
\hline 357 & Rio Grande Rise & $30^{\circ} 00,25^{\prime} \mathrm{S}$ & $35^{\circ} 33,59^{\prime} \mathrm{W}$ & 2086 \\
\hline
\end{tabular}

separated from the insoluble residue by using their slower gravitational settling times: starting with a well-mixed and suspended sample residue, the upper $9 \mathrm{~cm}$ of the water column in a $400 \mathrm{ml}$ beaker were siphoned off after $8 \mathrm{hr}$. of settling time. This process was repeated until, after 8 hours of settling time, the water column was clear. After the acid was washed out, a $0.5 \%$ sodium pyrophosphate solution in water was used in one washing to improve the suspension of clay minerals. For more details see Fenner (1982). This method effectively concentrates the equivalent quartz grain sizes larger than $2 \mu \mathrm{m}$.

Aroclor 4465 (n.d. = 1.66, solvent: Xylene; Göke, 1958) was used as the mounting medium.

Depending on the abundance of diatoms in a sample, all or half of a $20 \times 20 \mathrm{~mm}$ slide was scanned under the light microscope at a magnification of $1000 \times$ to determine the relative abundances of the diatom species.

\section{MATERIAL}

During the late Eocene to early Oligocene, Pacific DSDP Sites 65, 69, 71, 72, 73, 77, 161, 163, and 167 were located in the equatorial belt of high accumulation rates of biogenic silica (e.g., Boström et al., 1963, Leinen, 1981). Site 292 was located to the west of this zone of high productivity, possibly representing its western extension (Ingle et al., 1975). DSDP Sites 64 and 289, on the Ontong-Java Plateau, were $\sim 10^{\circ}$ of latitude further south than their present locations (Hammond et al., 1975), and DSDP Sites 216,217 , and 220 , in the Indian Ocean, were also about $10^{\circ}$ of latitude further south, just south of the equator (McElhinny, 1970; McKenzie and Sclater, 1971). At DSDP Site 357, on the Rio Grande Rise, which was always located outside of the equatoral and circum-Antarctic upwelling regions, only short intervals of diatom-bearing sediments occur, one in the lower middle Eocene, the other in the upper Oligocene. A similar pattern of restricted occurrence and preservation of siliceous microfossils in the lower middle Eocene and upper Oligocene also occurs at Site 356 on the São Paulo Plateau, at nearby DSDP Sites 22 and $516 \mathrm{~F}$ on the western Rio Grande Rise, and in the southwestern Brazil Basin at Site 515 (Maxwell et al., 1970; Shipboard Scientific Party, Leg 73).

\section{DSDP Sites 356 and 357 (Southwest Atlantic)}

In the Eocene of Sites 356 and 357 on the São Paulo Plateau and western Rio Grande Rise, diatoms are encountered only during a short interval within the upper part of Zone NP15 to the lower part of Zone NP16. At Site 357 diatoms are dissolved in the Eocene sediments above and below a short interval in Core 24 (Fenner, unpublished data). At Site $356,75 \mathrm{~m}$ of diatomaceous sediments of middle Eocene age are unconformably overlain by early Miocene and underlain by middle and early Eocene sediments barren of diatoms. This short interval of increased productivity and biogenic silica preservation is related to a short phase of volcanic activity in this region, combined with uplift and the presence of volcanic islands

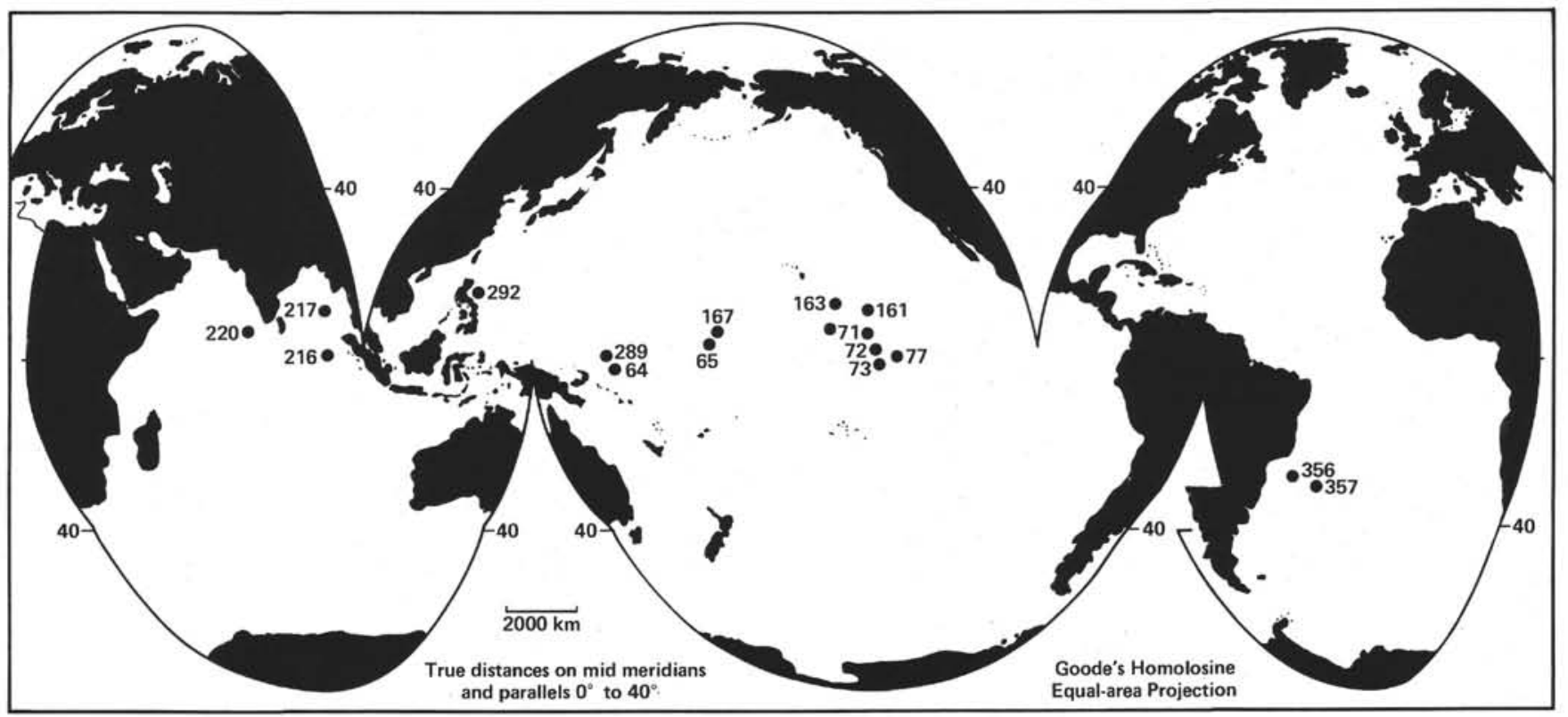

Figure 1. Geographic location of DSDP sites examined in this chapter. 


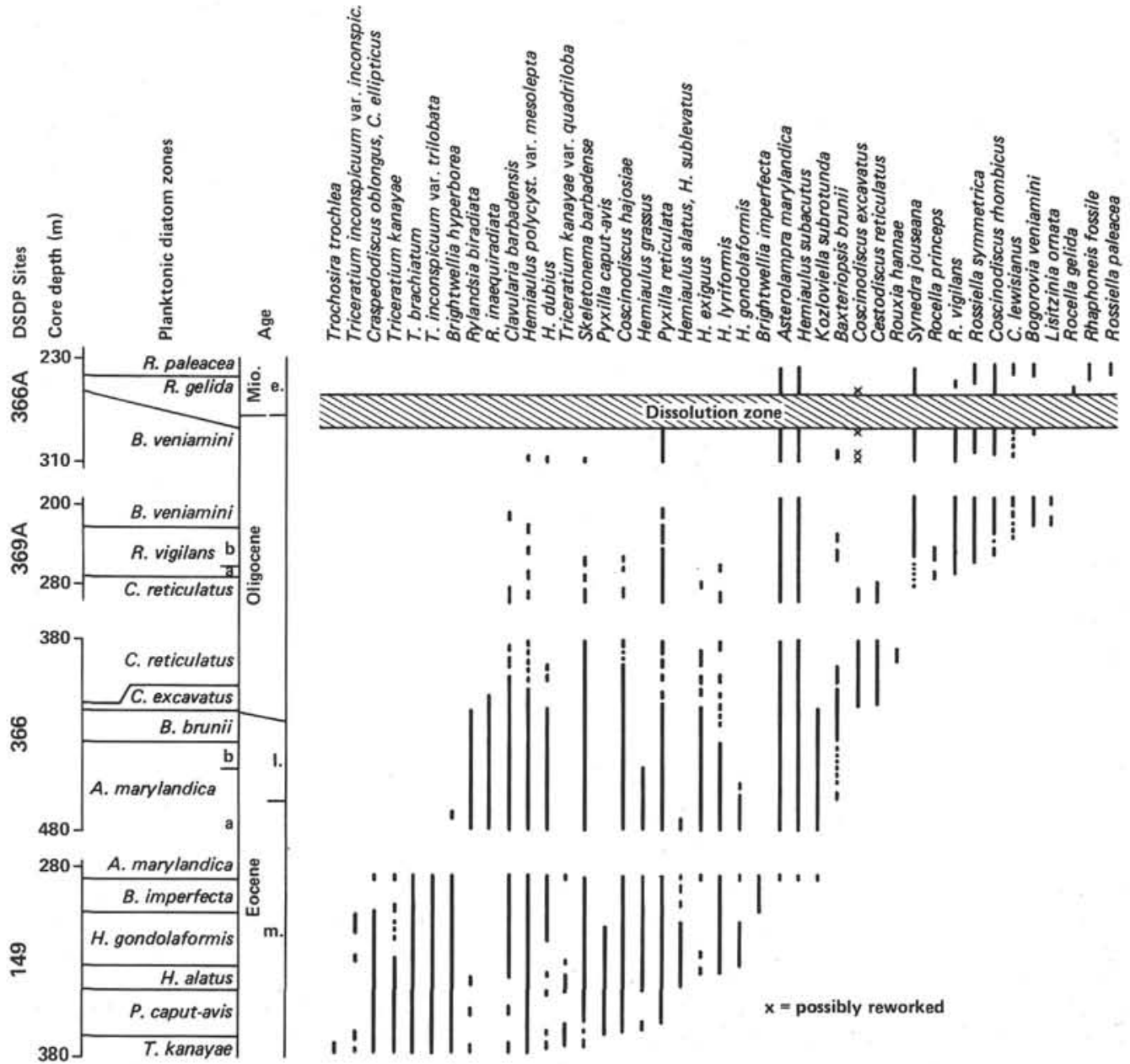

Figure 2. Eocene-Oligocene planktonic diatom zonation of Fenner (in press), as established for the low-latitude Atlantic and the Caribbean. Determination of other planktonic microfossil zones: Holes 366, 366A, 369A by Krasheninnikov and Pflaumann (1978), Cepek (1978), Johnson (1978); and Hole 149 by Hay and Beaudry (1973), Bukry (1973), and Riedel and Sanfilippo (1973). $1=T$. bromia and P. goetheana zones undifferentiated. Eocene/Oligocene boundary following Bukry (1978), who based it upon the LAD of Discoaster barbadiensis.

(Fodor and Thiede, 1977; Barker et al., 1981; Tjalsma, in press); thus it might be due in part to an "island effect."

The preservation of diatoms is much better at Site 356 (Cores 6-9) than at Site 357 (Core 24; Table 2). The dominant and characteristic species at Site 356 (Fig. 3) are (1) cosmopolitan species such as Asterolampra vulgaris, Brightwellia spp., Craspedodiscus oblongus, Hemiaulus polycystinorum var. mesolepta, Pyxilla reticulata, and tri- and quadrilobate varieties of Triceratium inconspicuum; and (2) low-latitude species as Clavularia barbadensis, $H$. alatus, $H$. altar, $H$. exiguus, $H$. polycystinorum var. dissona, $P$. caput-avis, $P$. gracilis, Skeletonema barbadense, and $T$. kanayae. $H$. grassus and $H$. gondolaformis among the low-latitude stratigraphic marker species were not found. As both species are very robust and dissolution-resistant, their absence could either indicate that they were geographically restricted to the low latitudes or could be due to the greater age of the sediments. The composition of the diatom assem- blages suggests that the first is the case. The succession of first and last occurrences of diatom species at Site 356 is the same as at Site 149 in the Caribbean, except for $C$. barbadensis, which seems to appear later at Site 356 . Thus the planktonic diatom zonation established in the low-latitude Atlantic and Caribbean (Fenner, in press) applies at Site 356.

The first consistent occurrence of Hemiaulus alatus in Core 7 and the presence of Pyxilla caput-avis, common Triceratium kanayae var. kanayae and $T$. kanayae var. quadrilobata in Cores 8 and 9 place Core 7 to 9 in the $H$. alatus Zone and Cores 8-9 below in the $P$. caputavis Zone. Because the low-latitude marker species $H$. gondolaformis is absent, Core 6 cannot be clearly placed into one of the low-latitude diatom zones. But the consistent presence of Clavularia barbadensis and the decrease in abundance of $T$. kanayae (both varieties) suggest that Core 6 has an age equivalent to that of the $H$. gondolaformis Zone of the low latitudes. The corre- 
Table 2. Diatom species occurrence in Eocene and Oligocene samples from Site 357, Rio Grande Rise.

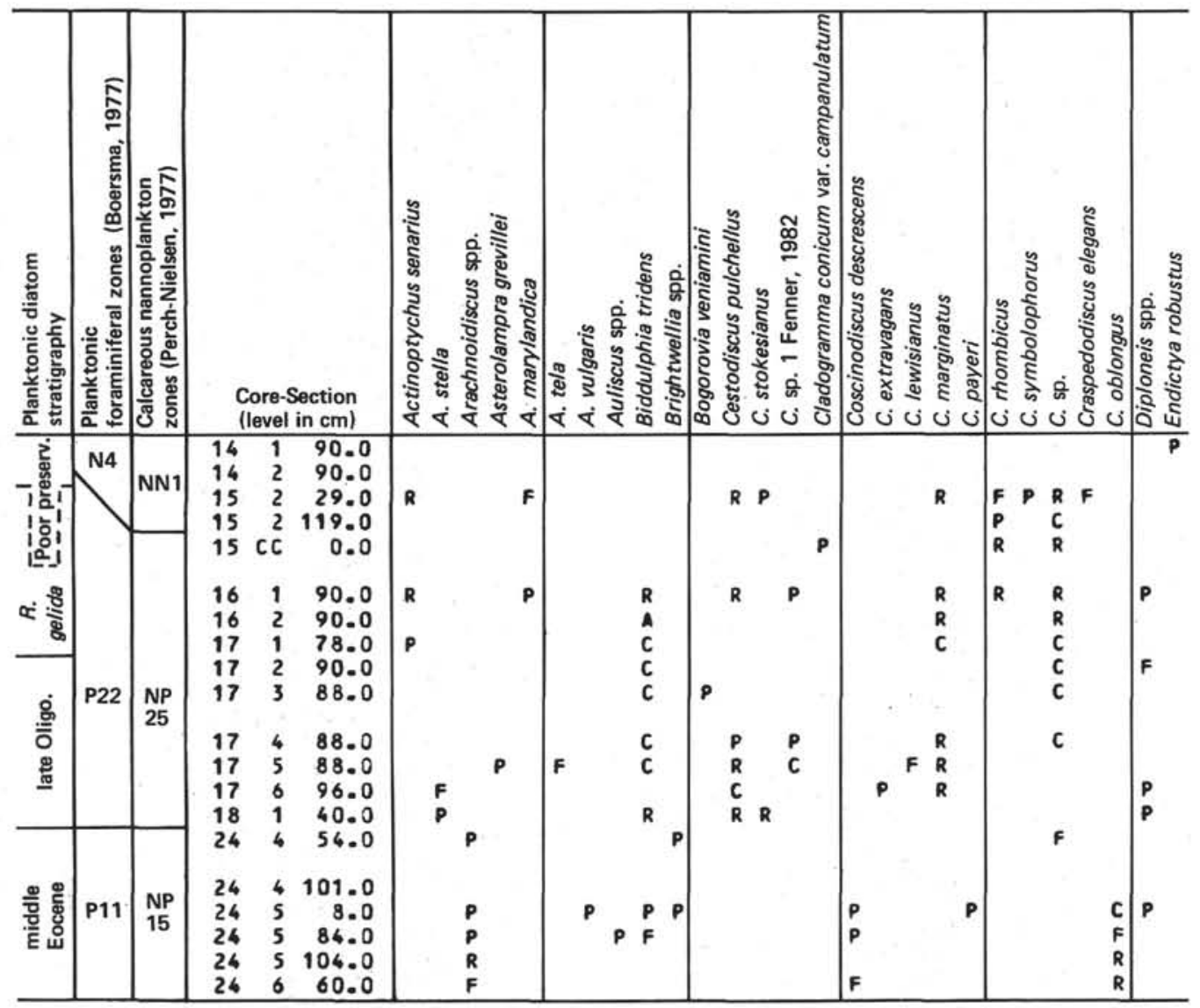

Note: The relative abundances are given as $P=<0.1 \%, F=0.1-1 \%, R=1-10 \%, C=10-30 \%, A=>30 \%$. Core $357-19$ to Section 357-24-4 was barren of diatoms as were Core 25 and below. In addition to the species listed, the following occurrences were noted: Spermatogonia spp., Sample 357-15,CC (P); Macrora barbadiensis (silicoflagellate), Samples 357-245. 8-9 cm (P), and 357-24-6, 60-61 cm (P); freshwater diatoms (A. granulata), Samples 357-16-1, 90-91 cm (F), 357-16-2, 90-91 cm (P), 357-17-6, 96-97 cm (P), and 357-18-1, 40-41 cm (P).

lation of the ranges of stratigraphically important diatom species and the planktonic diatom zones to the calcareous microfossil zones at this site is given in Figure 3.

At DSDP Site 357, further east on the western Rio Grande Rise, diatom preservation in the middle Eocene diatomaceous section is relatively poor and most of the low-latitude species such as T. kanayae, Clavalaria barbadensis, and Skeletonema barbadense, which are still present at DSDP Site 356, are not found. Only the very robust $P$. caput-avis is present. But as the also very robust $T$. kanayae is missing from the assemblage, the absence of these low-latitude species at this site during this interval is interpreted as being due to paleogeographic restriction (as Boersma [1977] reported also for the planktic foraminifers), rather than as being due to selective dissolution. Whether $H$. alatus is absent for stratigraphic or paleogeographic reasons cannot be decided. Further south, in the middle Eocene section of DSDP Site 512 on the Falkland Plateau (Gombos, 1983), all of the low-latitude species are definitely no longer present. Because most of the low-latitude marker species are absent, the occurrence of $P$. caput-avis, Craspedodiscus oblongus, and $T$. inconspicuum var. inconspicuum with P. reticulata allows us to place Core 24 of Site 357 into the middle Eocene only, with an age equivalent to some- where within the $P$. caput avis-H. alatus-H. gondolaformis low-latitude zones. This age determination is in agreement with the dating by calcareous nannofossilsupper part of Zone NP15 (Discoaster bifax Subzone) according to Perch-Nielsen (1977) and Bukry (1977)and the planktonic foraminifers-Zone P11 (Boersma, 1977).

The second diatomaceous interval in the Paleogene of Site 357 (Cores 15-18) occurs in the upper Oligocene (Table 2, Fig. 4). The diatom assemblages are characterized by the frequent occurrence of Synedra jouseana and, in addition, Asterolampra tela, Bogorovia veniamini, Coscinodiscus extravagans, C. lewisianus, $C$. rhombicus, Hemiaulus subacutus, Lisitzinia ornata, Rocella gelida, $R$. princeps, $R$. vigilans, and Rossiella symmetrica species indicating a late Oligocene age. The first occurrence of Rocella gelida is used in the circumAntarctic and in the low latitudes to define the base of the $R$. gelida Zone (Fenner, in press). The diatomaceous section does not extend beyond the earliest Oligocene, as is indicated by the presence of Hemiaulus taurus and Rocella schraderi. Neither species known to occur just above the Oligocene/Miocene boundary (e.g., Rhaphoneis fossile and Rossiella paleacea, typical in low-latitude sites; Fenner 1982) nor the cosmopolitan species 
Table 2. (Continued).

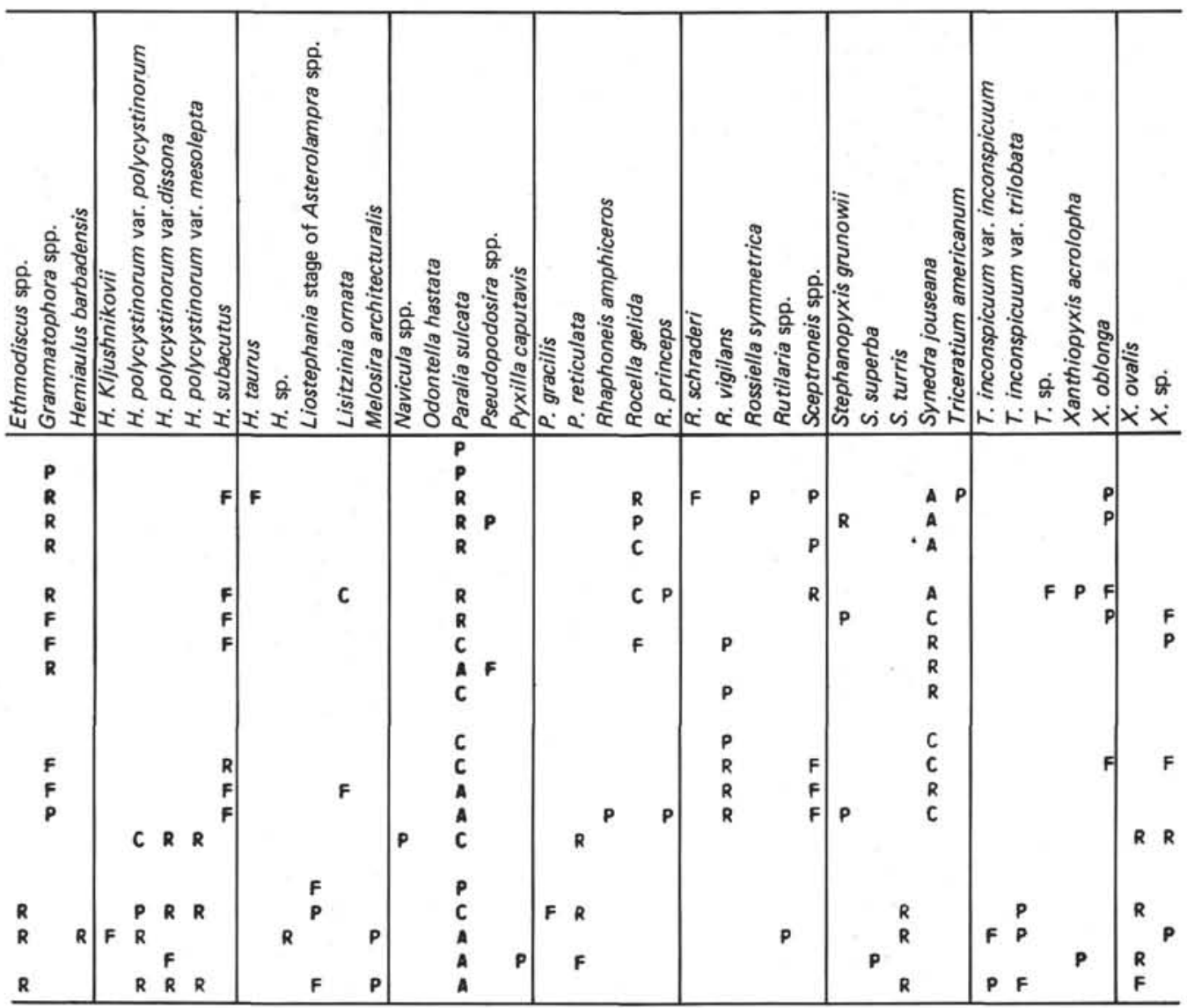

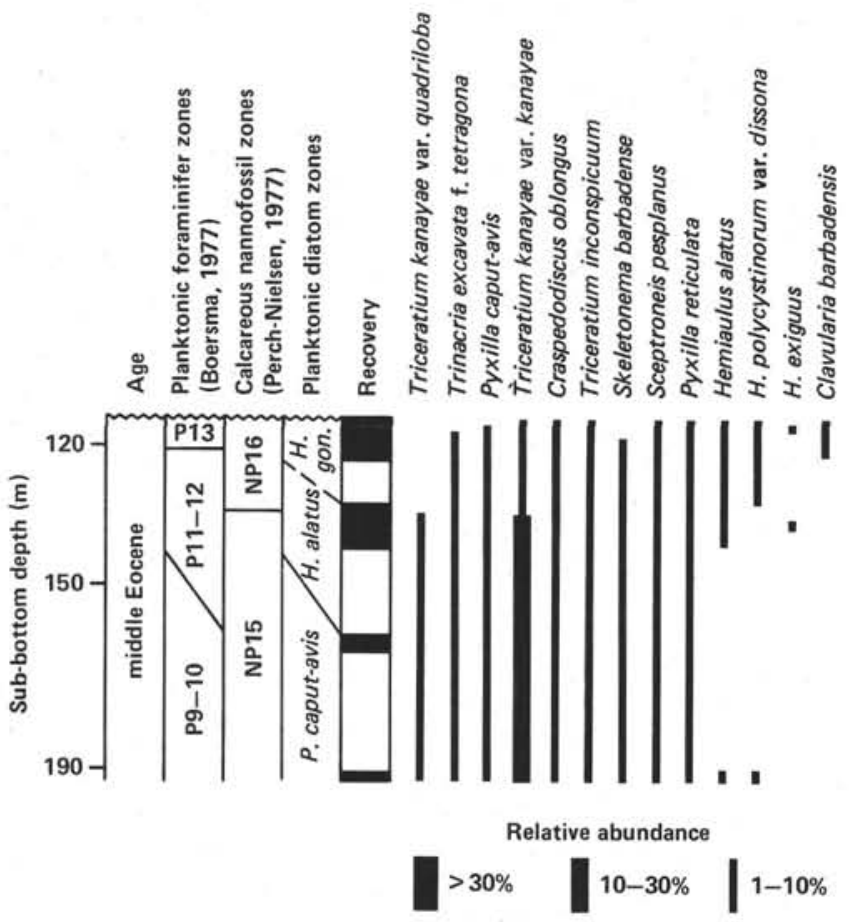

Figure 3. Ranges of stratigraphically important diatom species in middle Eocene cores of DSDP Site 356, São Paulo Plateau.

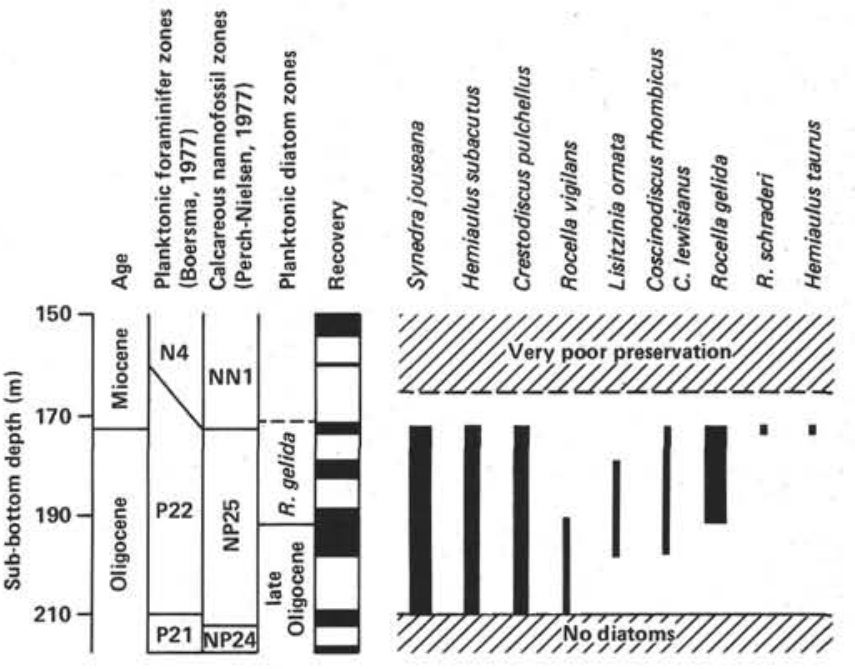

Figure 4. Ranges of stratigraphically important diatom species in lace Oligocene core of DSDP Site 357, Rio Grande Rise. Relative abundance as in Figure 3.

Rhaphidodiscus marylandicus and Thalassiosira fraga, were found.

Most of the late Oligocene species occurring at Site 357 (C. rhombicus, B. veniamini, L. ornata, Rossiella symmetrica and $S$. jouseana) are known to be cosmopolitan (Fenner, 1982). Only one species, which seems 
to be restricted to the low and middle latitudes (Hemiaulus subacutus) is present at this site. Other species, occurring at this site in the latest Oligocene, such as $H$. taurus, are typical high southern latitude species, thus making application of the circum-Antarctic planktonic diatom zonation more appropriate and reflecting an extension of "cool," high-latitude species toward the equator. A comparison with the Eocene diatom assemblages described from the Falkland Plateau (Gombos, 1976; Gombos and Ciesielski, 1983; Gombos, 1983; Fenner, in press) shows that on the Falkland Plateau in the middle Eocene (upper Lutetian; Gombos, 1983) the diatom assemblages were characterized by the absence of typical low-latitude species, and at least one indigenous circum-Antarctic species had already developed $(H$. vitreus). In the late Eocene and early Oligocene, the number of indigenous circum-Antarctic diatom species increases with the first appearances of $H$. caracteristicus, $H$. pacificus, and $H$. rectus var. twista, which are common elements of the assemblages. But these species remained restricted to the circum-Antarctic region and were not found at the São Paulo Plateau or Rio Grande Rise. Typical high southern latitude species did not extend toward the equator before the latest Oligocene.

The good preservation of diatoms in the upper Oligocene sediments (Site 357) on the western Rio Grande Rise is correlated to increased sediment accumulation rates, from $5-7 \mathrm{~m} / \mathrm{m}$.y. in the diatom-barren sediments below to $\sim 30 \mathrm{~m} / \mathrm{m} . \mathrm{y}$. in the diatomaceous section (Perch-Nielsen et al., 1977). The calcium carbonate content of the sediment is constant at about $80 \%$ (Fenner, unpubl. data). In the diatomaceous interval traces of volcanic ash are found (Perch-Nielsen et al., 1977). Opal phytoliths, which are siliceous fillings of the epidermal cells of Gramineae and Equisetales, and thickly silicified valves of the freshwater diatom, Aulacosira granulata, occur consistently during this interval, whereas in the interval of increased preservation of siliceous skeletons during the middle Eocene no freshwater diatoms were found and only rare, single, opal phytoliths (Fenner, unpubl. data). The biosiliceous terrigenous components could be derived from nearby volcanic islands (for which there is no evidence in the late Oligocene) or from the South American hinterland. Their presence in marine sediments might be correlated to increased aridity and/or wind intensity around the time of the Oligocene/Miocene boundary. On the Sierra Leone Rise off Northwest Africa, an identical increase in the abundance of land-derived biosiliceous particles is observed (Fenner, 1982).

\section{Equatorial Pacific Sites (Table 3)}

In the equatorial Pacific sites, except for Site 167, preservation of diatoms in the Eocene is very poor because of dissolution and silica diagenesis, but in the early Oligocene it is moderate to good. This offers us the opportunity to study the paleogeographic distribution of the diatom species found to be characteristic of the low-latitude Atlantic Ocean (Fenner, 1982) and to test the planktonic diatom zonation established there (Fenner, in press).
At all sites, the same Cestodiscus spp.-dominated assemblage was found in the early Oligocene as is present in the equatorial Atlantic. Characteristic species were $C$. gemmifer, $C$. convexus, $C$. reticulatus, C. trochus, $C$. parmula, Coscinodiscus excavatus, $C$. oligocenicus. Furthermore, the late Eocene diatom assemblages found at Site 167 are characterized by the same species that dominated the low-latitude Atlantic diatom assemblages.

\section{Site 64}

This site on the Ontong-Java Plateau was spot-cored. Sample 64-10-1, 70-74 cm, at $847 \mathrm{~m}$ depth, has a typical early Oligocene diatom assemblage dominated by Cestodiscus gemmifer and C. parmula. Because the two stratigraphic guide species, C. reticulatus and Coscinodiscus excavatus, co-occur, this sample was assigned to the Cestodiscus reticulatus Zone. This age assignment is in accordance with the biostratigraphic results of Bukry (1971a), Martini and Worsley (1971), and Gartner (1971), who place Section 64-10-1 in Zone NP24 (Helicosphaera reticulata Zone). Deeper samples belong in the Eocene. Diatom preservation is poor.

\section{Site 65 (Table 3)}

This site in the central basin of the central equatorial Pacific was continuously cored. Thin chert layers and thin layers of turbidite sediments occur in the lower Oligocene and upper Eocene (Heath and Moberly, 1971a, b). The turbidites explain the presence of occasional well-preserved calcite tests, which must have originated above the contemporary calcite compensation depth. Throughout the sequence, reworked middle Eocene radiolaria are reported by Riedel and Sanfilippo (1971). However, reworking did not seem to be a major factor in the samples examined for this study. Only one evidently reworked Hemiaulus was found, in Sample 65-16-2, $82-86 \mathrm{~cm}$. The presence of Coscinodiscus excavatus in Sample 65-14-1, 70-74 cm, together with the absence of Cestodiscus reticulatus, places this sample in the $C$. excavatus Zone, which is in accordance with the age determination by calcareous nannofossils (Bukry, 1971a) as Helicosphaera reticulata to Discoaster barbadiensis zones. The poor preservation of diatoms in samples from Cores 15 and 16, and from Hole 65.1 does not allow a more detailed age assignment than late Eocene, so that a test of the completeness of the upper Eocene section is impossible.

\section{Site 69A}

Planktonic diatoms place Sample 69A-8-1, 70-74 cm in the Cestodiscus reticulatus Zone, agreeing with the age given by calcareous nannofossils and planktonic foraminifers (Helicopontosphaera reticulata Zone or Discoaster tani ornatus Zone, respectively [Bukry, 1971b; Haq and Lipps, 1971] and Zone P20 to P18 [Beckmann, 1971]). There is a sharp change in lithology from the calcareous nannofossil ooze in Core 69A-8 to the radiolarian ooze below. Cores 69A-9 and 69A-10 are placed in the Thyrsocyrtis bromia Zone (Moore, 1971). The diatoms suggest an earliest Oligocene age in the Coscinodiscus excavatus Zone, because Cestodiscus reticu- 
latus is absent and Coscinodiscus excavatus and Thalassiosina bukryi are present. There is no reason to believe that the occurrence of these species is due to downhole contamination, as was suggested for the radiolarians by Moore (1971). In Core 69A-11 only one species, Riedelia pacifica, was found. Radiolarians place this core in the middle Eocene Thyrocyrtis triacantha Zone (Moore, 1971). Sample 69-6-1, 72-76 cm is also within the middle Eocene, based on the presence of Hemiaulus polycystinorum var. asymmetrica and Odontella hastota. Radiolarian stratigraphy assigns this sample to the middle Eocene Podocyrtis chalara Zone (Moore, 1971). This suggests that the upper Eocene section is missing at this site.

\section{Site 71A}

The three spot cores studied at this site did not recover diatoms across the Eocene/Oligocene boundary. Core $71 \mathrm{~A}-1$ is assigned to the early Oligocene Cestodiscus reticulatus Zone, which is in agreement with the age determinations made on the basis of planktonic foraminifers (Zone P18-19), calcareous nannofossils, and radiolarians (Thyrsocyrtis tuberosa Zone) by Beckmann (1971), Haq and Lipps (1971), Bukry (1971b), Hay (1971), and Moore (1971). In Cores 71A-2 and 71A-3, which are probably of late Eocene age ( $T$. bromia Zone; Moore, 1971), no diatoms were present.

\section{Site 72}

The lower Oligocene and upper Eocene were continuously cored, but the lower Oligocene section is incomplete and the Eocene section badly contaminated by younger material. Only one sample was examined from this site (Sample 72-9-1, 70-74 cm); it is placed in the earliest Oligocene.

\section{DSDP Site 73 (Table 4)}

At this continuously cored site, a short hiatus at the Eocene/Oligocene boundary is indicated by calcareous nannofossils (Bukry, 1971b). High abundances of downmixed, well-preserved Neogene diatoms are seen in the uppermost section of each core. Eocene-Oligocene diatoms, by contrast, are poorly preserved and only the most dissolution-resistant species are present. The interval from Core 73-15 to Section 73-19-3 is assigned to the early Oligocene Cestodiscus reticulatus Zone based on the presence of $C$. reticulatus. Coscinodiscus excavatus, which is known from other equatorial sites to range below Cestodiscus reticulatus, is found only as far down as Section 73-18-5, although it is a very robust and also relatively dissolution-resistant species. There are two possibilities. C. excavatus may be absent from Core 73-19 because of dissolution. This point is supported by the high abundance of Cestodiscus spp. down to Section 73-19-3 that gives this section a typical early Oligocene character. Alternatively, the presence of $C$. reticulatus in Core 73-19 might be due to downhole contamination into a barely recognizable late Eocene assemblage. Such contamination is definitely evident in the presence of down-worked Neogene diatom species. Age determinations using planktonic foraminifers and calcareous nan- nofossils (Bukry, 1971b; Haq and Lipps, 1971; Hay, 1971; Beckmann, 1971) place Core 73-19 in the late Eocene or later middle Eocene. Below Section 73-19-3, preservation of diatoms becomes very poor.

\section{Site 77B}

Diatom preservation in this continuously cored early Oligocene site is moderate to good, allowing determination of the Cestodiscus reticulatus and Coscinodiscus excavatus zones. The assemblages are dominated by species of the genus Cestodiscus. Diatoms are absent from Cores 52 and 53 (both Eocene).

\section{Site 161A}

The lithology changes from nannofossil chalk in the lower Oligocene (Cores 161A-2 to 161A-9) to radiolarian ooze in the upper and middle Eocene below. Cores $161 \mathrm{~A}-2$ to $161 \mathrm{~A}-9$ are assigned to the early Oligocene Cestodiscus reticulatus Zone because $C$. reticulatus cooccurs with Coscinodiscus excavatus. Preservation of diatoms is moderate. Below, in Cores $161 \mathrm{~A}-10$ to $161 \mathrm{~A}-14$ preservation of diatoms is extremely poor. The absence of the early Oligocene marker species and the presence of Cestodiscus trochus and Kozloviella meniscosa suggest a late Eocene age for Cores 161A-10 and 161A-11.

\section{Site 163}

The early Oligocene and Eocene at this site is almost barren of calcareous microfossils. The clayey diatomaceous ooze of Sample 163-4-1, 70-74 cm is placed in the Cestodiscus reticulatus Zone, which is in agreement with the age determination using radiolarians (Thyrsocyrtis tuberosa Zone, Dinkelman, 1973). In the Eocene radiolarian ooze below, thin chert layers are found and preservation of diatoms is poor. The assemblages are dominated by Riedelia pacifica and Coscinodiscus marginatus.

\section{Site 167 (Fig. 5)}

At this site on the Magellan Rise, the zonations of the planktonic calcareous microfossils (Douglas, 1973; Roth, 1973) show no hiatus at the Eocene/Oligocene boundary. Although diatom valves show definite dissolution, their preservation is moderate-enough to apply the planktonic diatom zonation of Fenner (in press). The Eocene/Oligocene boundary is not associated with a strong change in preservation. At this site the sequence of first appearances just below and just above the Eocene/Oligocene boundary is the same as in DSDP Site 366, in the equatorial Atlantic (Fenner, 1982). Thalassiosira bukryi appears first, followed by Coscinodiscus excavatus and then Cestodiscus reticulatus, placing the Eocene/Oligocene boundary between Samples 167-24-1, $48-53 \mathrm{~cm}$ and $167-25, \mathrm{CC}$. Large specimens of $C$. pulchellus var. novazealandica are common during the interval of transition from the Eocene to the Oligocene. Kozloviella subrotunda, Asterolampra punctifera, Coscinodiscus descrescens, and Hemiaulus polycystinorum var. mesolepta last occur below the Eocene/Oligocene boundary. The decrease in abundance of valves of Hemiaulus spp. 
Table 3. Diatom species occurrences in Eocene and Oligocene samples from DSDP sites in the central equatorial Pacific and Ontong-Java Plateau.

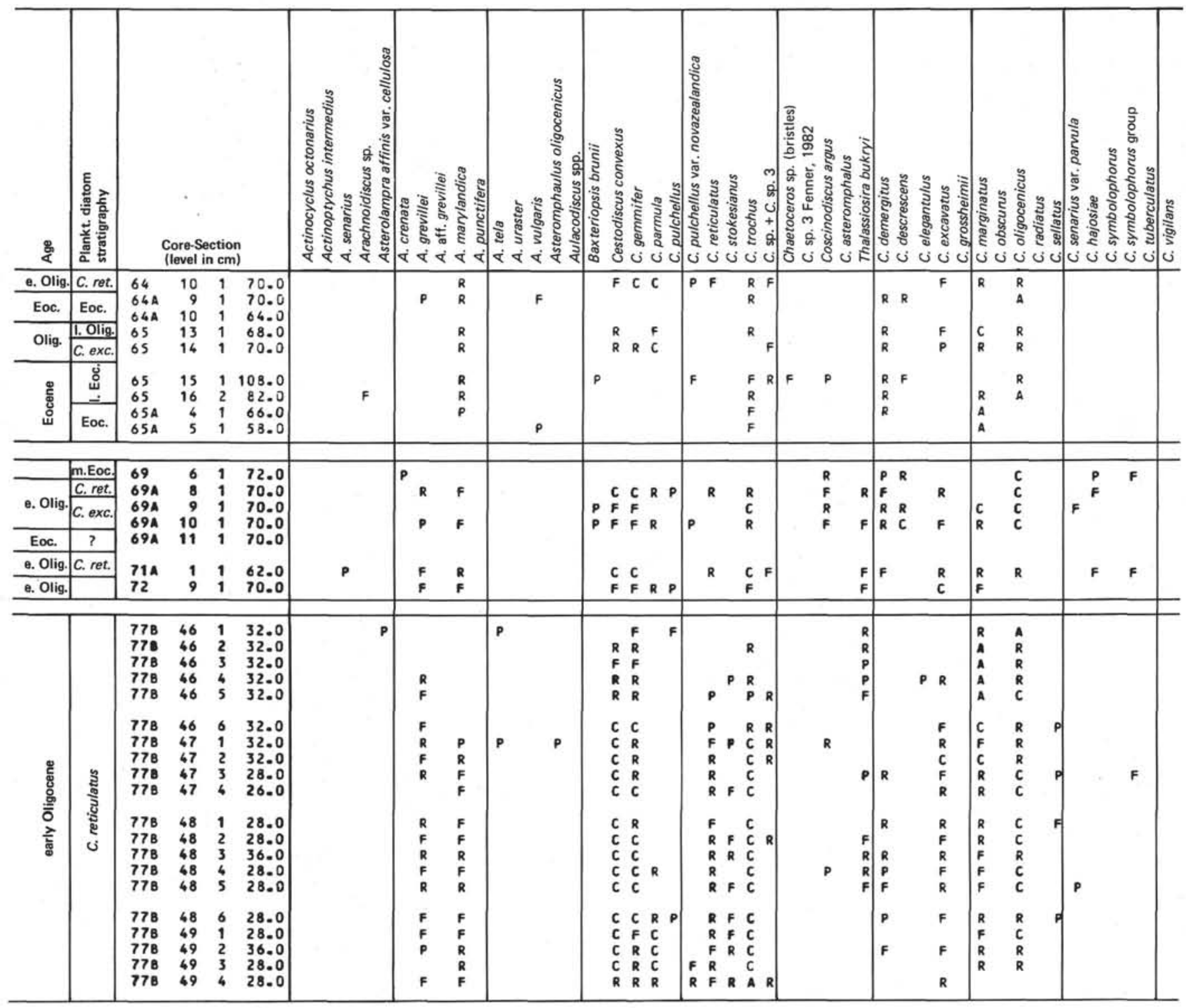

is not so drastic as at Site 366 , but the increase in valves of Cestodiscus spp. is as dramatic. Samples 167-25,CC to $167-27, \mathrm{CC}$ are placed in the late Eocene Baxteriopsis brunii Zone, using the first appearance of $B$. brunii. Samples $167-28-1,59-63 \mathrm{~cm}$ to $167-32-2,59-63 \mathrm{~cm}$ belong in the A. marylandica Zone.

In Cores 33-to 35, chert is common and no diatoms are preserved.

\section{Site 289 (Fig. 6)}

At this site on the Ontong-Java Plateau, the preservation of the diatom valves is moderate to poor throughout the lower Oligocene and upper Eocene. Only in Core 106 (just above the chert) does preservation become very poor. The first occurrences of Coscinodiscus excavatus and Cestodiscus reticulatus place the Eocene/Oligocene boundary between Cores 101 and 102 . The change in assemblage composition to an assemblage dominated by Cestodiscus spp. occurs slightly below, between Cores 102 and 103. The late Eocene preservation of diatoms is poor. The identification of the planktonic diatom zones therefore has to be viewed with caution. The calcareous nannofossil indicate a short hiatus at the Eocene/Oligocene boundary (Shafik, 1975).

\section{Site 292}

At this site on the Benham Rise, a small hiatus at the Eocene/Oligocene boundary is indicated by calcareous nannofossils (Ellis, 1975). The preservation of diatom valves at this site is poor, with an interval of especially intense biogenic silica dissolution during the earliest Oligocene (Cores 33-35) that reaches its maximum in Sample 292-33-1, 10-14 cm, which is completely barren of diatoms. In the late Eocene, Grammatophora spp. are common in the diatom assemblages, indicating a shallow-water environment. The last occurrence of Incertae Sedis: Genus et species indet. (3) correlates with the nannofossil-determined Eocene/Oligocene boundary. Samples from Core 39, Section 2 are barren of diatoms. 
Table 3. (Continued).

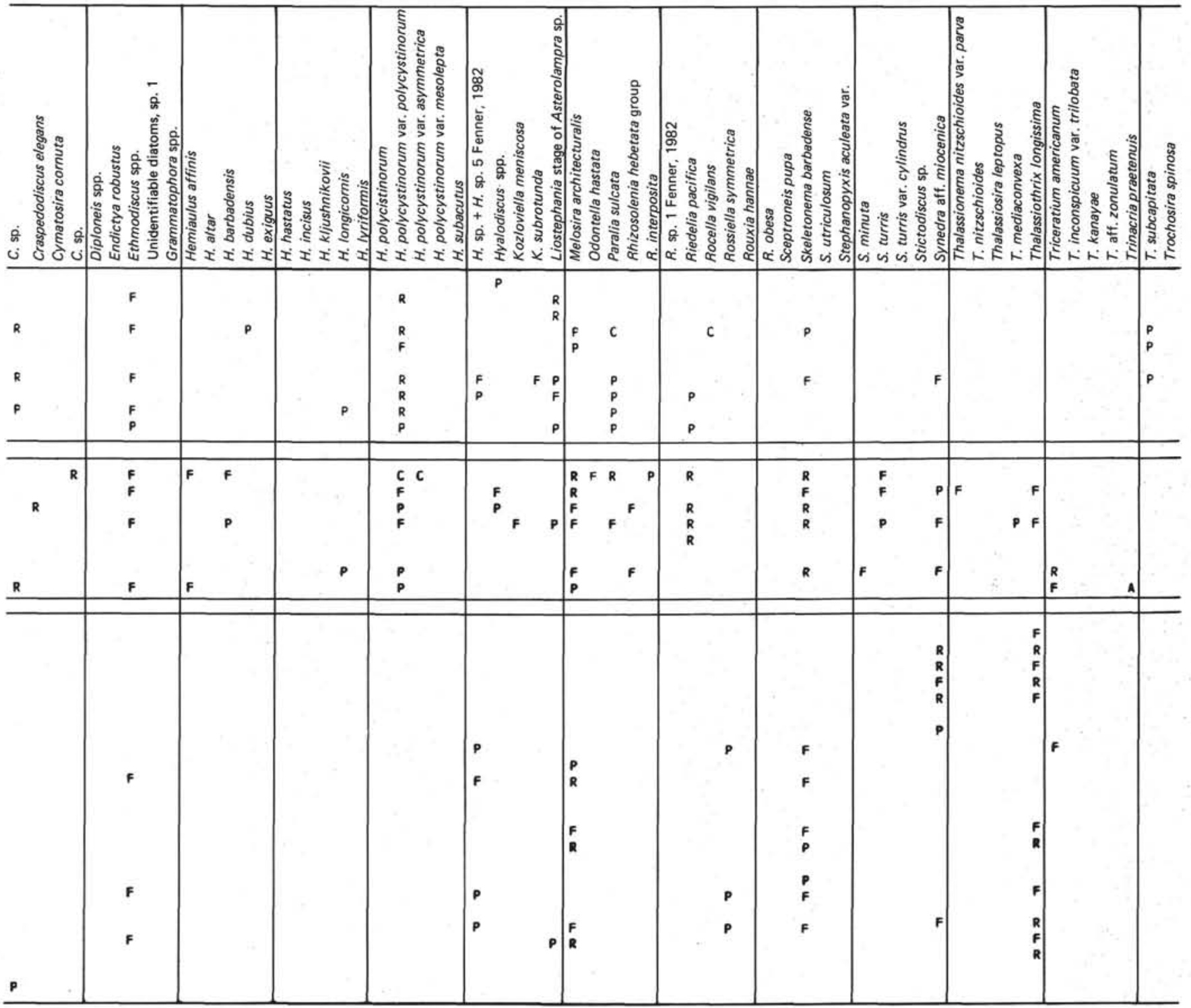

\section{Indian Ocean Sites (Table 5)}

\section{Sites 216 and 217 (Table 5)}

During the Late Cretaceous and Paleocene, both sites, located on the Ninetyeast Ridge (Table 1), experienced biosiliceous accumulation that continued at the more southern Site $\mathbf{2 1 6}$ into the middle Eocene. With continuing northward plate movement (McElhinny, 1970; McKenzie and Sclater, 1971, Whitemarsh et al., 1974) these two sites gradually moved out of the belt of high primary productivity. At both sites late Eocene and Oligocene nannofossil chalks with rare and poorly preserved diatoms were deposited at the northern fringe of the high-productivity belt. The poor preservation of diatoms at both sites allows no exact determination of the Eocene/Oligocene boundary.

Site 216

The Eocene/Oligocene boundary must be placed below Sample 216-13-1, 144-149 cm, using the first occur- rence of Cestodiscus reticulatus as definite early Oligocene. Using calcareous nannofossils and planktonic foraminifers, Gartner (1974), Bukry (1974), and Berggren et al. (1974) place the Eocene/Oligocene boundary at a deeper level, within Core 15.

\section{DSDP Site 217}

The last abundant occurrence of Hemiaulus spp. is in Sample 217-9-5, 59-64 cm. This, and the presence of Kozloviella subrotunda in Sample 217-9-6, 77-82 cm, place the Eocene/Oligocene boundary between Samples 217-9-4, 41-46 cm and 217-9-6, 77-82 cm. Calcareous microfossils (Gartner, 1974; Bukry, 1974; Berggren et al., 1974) place the Eocene/Oligocene boundary between Sections 217-9-5 and 217-9-6.

\section{Site 220 (Table 6)}

At this site, at the southeastern tip of the Arabian Basin, diatom abundance, diversity, and preservation decrease from the middle Eocene toward the late Eocene. 
Table 3. (Continued).

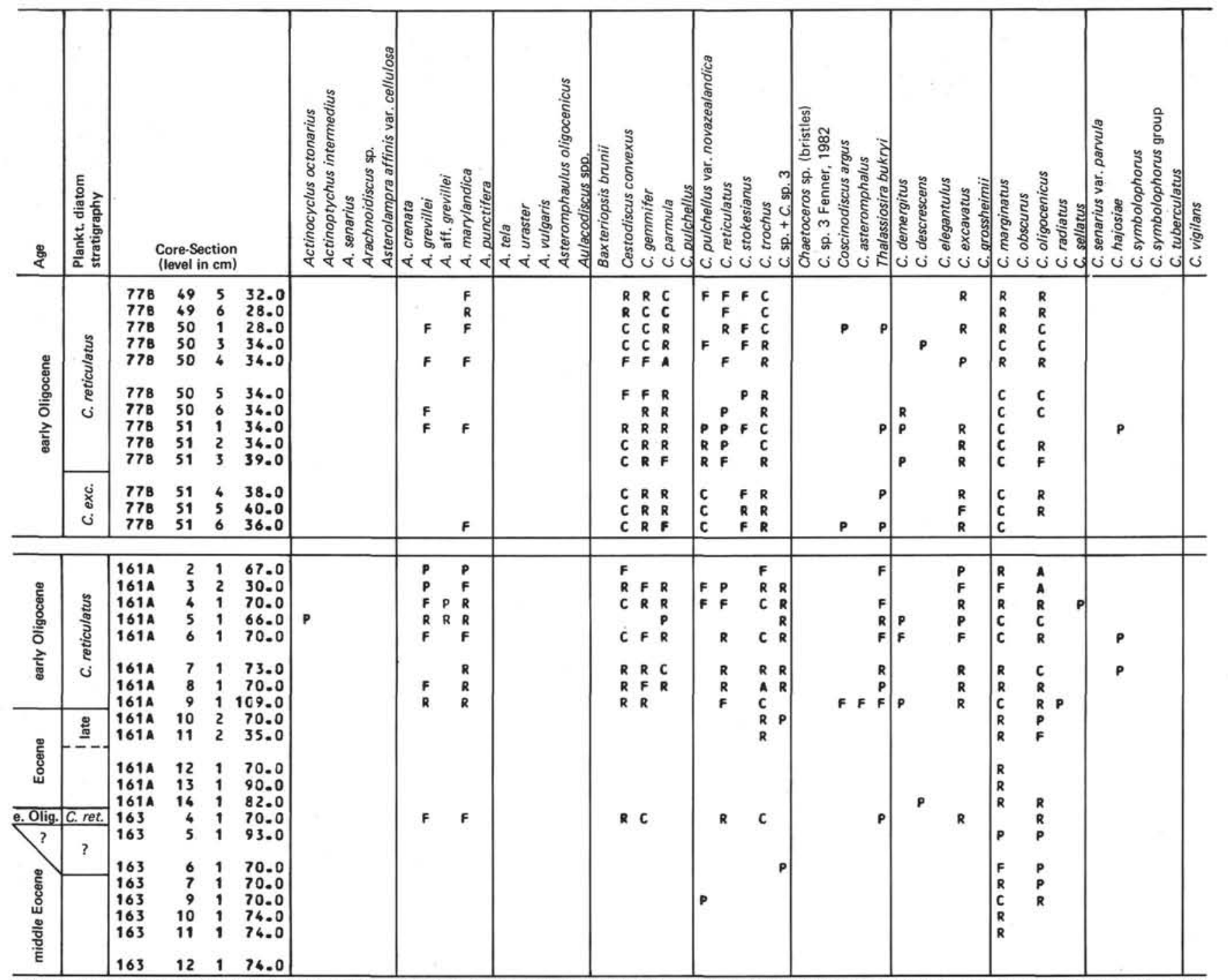

Note: For explanation of the above symbols, see Table 2. In addition to these species, the following occurrences were observed: Spermatogonia spp.: Samples 64-10-1, 70-74 cm (P). 72-76 cm (F), 163-9-1, 70-78 cm (F), 167-24-1, 48-53 cm (F), 167-32-2, 59-63 cm (P), 289-94-2, 55-60 cm (P), 289-97-1,120-125 cm (P), 289-97-4, 122-127 cm (F), 289-98-2, (P), 65-13-1, 68-72 cm (P), 77B-46-1, 32-38 cm (P), 161A-5-1, 66-70 cm (P), 167-22-1, 59-64 cm (P), 289-94-2, 55-60 cm(P), 289-94-3, 55-60 cm (P), 289-97-4, 122-127 cm (P), 292-36-3, 129-133 cm (R), 292-36,CC (F), 292-37-1, 129-134 cm (F).

No Oligocene samples were available for study. Because Triceratium kanayae is present, Sections 220-12-4 to 220-15-1 are considered middle Eocene.

\section{DISCUSSION}

The assemblage analysis of the early Oligocene at the equatorial Pacific sites shows that the same new species of the genera Cestodiscus (C. gemmifer, $C$. reticulatus, $C$. convexus, and $C$. parmula) and Coscinodiscus (C. excavatus), which dominate the assemblages in the equatorial Atlantic are also dominant in the equatorial Pacific. Data from Site 167 show that the same is true for the latest middle and late Eocene. The characteristic and dominant species are Baxteriopsis brunii, Clavularia barbadensis, Hemiaulus polycystinorum var. mesolepta, $H$. longicornis, $H$. subacutus, and Skeletonema barbadense. Ages determined by the ranges of stratigraphic marker species from the equatorial Atlantic and Caribbean (Sites 149, 366, 369A; Fig. 2) agree with those de- termined by calcareous microfossils. Such a homogeneous circum-equatorial species distribution and equal sequence of datum planes is a result of the open, lowlatitude seaway between the Atlantic and Pacific and reflects a circum-equatorial circulation in Tethys.

The mid-latitude position of Sites 356 and 357, on the Sao Paulo Plateau and Rio Grande Rise, makes it possible to recognize latitudinal shifts in assemblage distributions. In the middle Eocene of Site 357, the assemblage is composed of low-latitude species and cosmopolitans; only two of the typical low-latitude stratigraphic marker species, Hemiaulus grassus and $H$. gondolaformis, are missing. Further south, on the Falkland Plateau, (Gombos, 1983) all the low-latitude species are absent; one indigenous circum-Antarctic species (Hemiaulus vitreus) is already present. In the late Eocene and early Oligocene, the number of indigenous circum-Antarctic planktonic diatom species increases to at least three-Hemiaulus caracteristicus, $H$. pacificus, and $H$. rectus var. 
Table 3. (Continued).

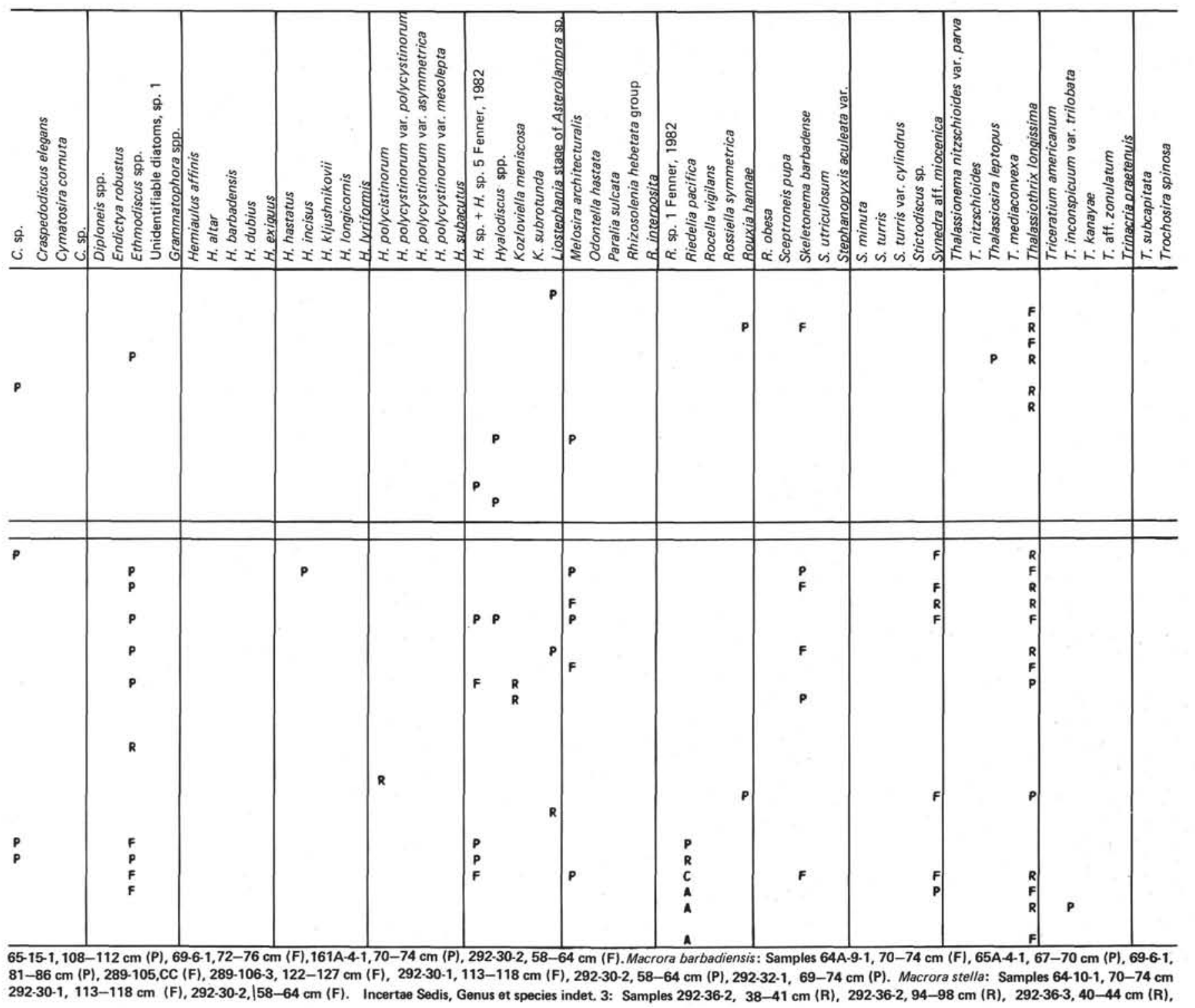

twista, which remain restricted to the circum-Antarctic belt. Only during the latest Oligocene do high-latitude diatom species spread as far toward the equator as the Rio Grande Rise. This extension of high-latitude "cool" species in the latest Oligocene seems to be correlated to a period of increased sediment accumulation, productivity, and wind intensity at Sites 357 and 516. Increased productivity and wind intensity were also found for the same time interval at Hole 366A (Fenner, 1982) and thus seem to be an event of more than local importance.

At Site 167 diatom preservation was moderate in the late Eocene, thus allowing us to test the extent of the assemblage change found in equatorial Atlantic Site 366 (Fenner, 1982), which is correlated there to the strong shift in oxygen isotopes near the Eocene/Oligocene boundary (Vergnaud Grazzini and Rabussier-Lointier, 1980). No mass extinctions of planktonic diatom species occurred at the Eocene/Oligocene boundary at Sites 366 or 167, but a decrease in abundance of Hemiaulus spp. and a strong increase in abundance of Cestodiscus spp. at both sites occurred at the base of the Coscinodiscus excavatus Zone.

The percentage of Cestodiscus spp. in the late Eocene is about $10-20 \%$. Their abundance strongly increases at the base of the $C$. excavatus Zone to $40-60 \%$. As both genera Hemiaulus and Cestodiscus produce very robust and relatively dissolution resistant species, dissolution, unless it is very strong, should not mask this assemblage change. Indeed, in many other equatorial sites with more poorly preserved diatom assemblages (Sites 64,65 , 161 , and 163) the strong increase in abundance of Cestodiscus spp. occurs at the base of the Coscinodiscus excavatus Zone. But this assemblage composition change is not always correlated with the base of the $C$. excavatus Zone. In other equatorial sites (Sites 69, 292, 216, 217) it occurs in the earliest Oligocene and at Sites 73 and 289 in the late Eocene.

A strong change in assemblage composition occurring so widely in the equatorial regions is most easily interpreted in terms of response to changing ecological pa- 
Table 3. (Continued).

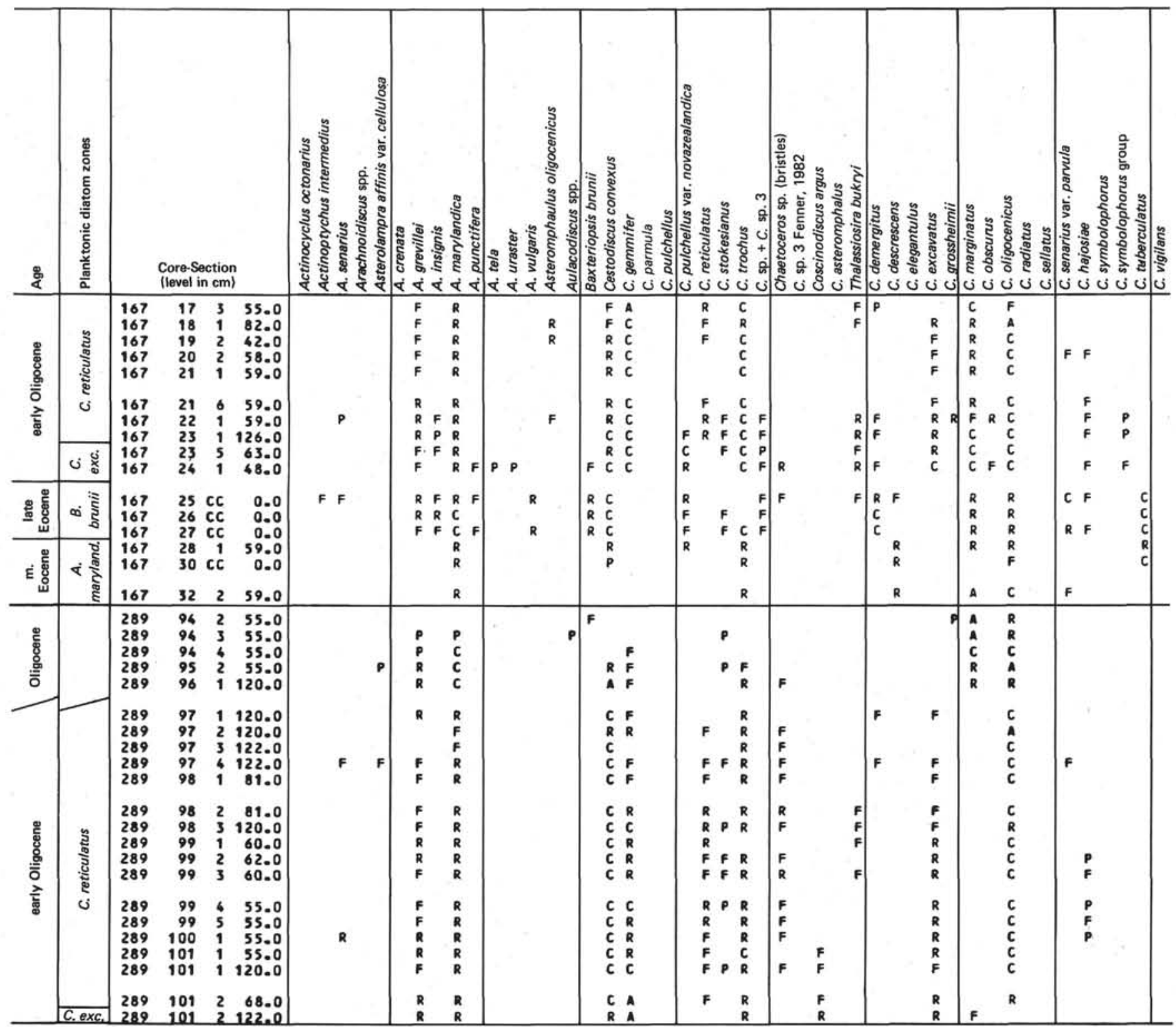

rameters and suggests that the tectonic, climatic, and oceanographic changes that occurred close to the Eocene/Oligocene boundary were not only a high-latitude and bottom-water event, but must also have had a strong impact on surface waters in low latitudes. The factors or combination of factors important in causing the change in assemblage composition cannot be determined from available data. Oxygen isotope data (Douglas and Savin, 1975, Keigwin, 1980) suggest that the temperature decrease in the surface water of the low latitudes was small, but that the water column became stratified by cold bottom-water formation. Changes in stratification in the water column and vertical and horizontal circulation are major influences in nutrient recycling. Indications for such changes are discussed in Johnson (in press). Unfortunately, no oxygen isotope determinations yet exist for the equatorial Pacific sites in which diatoms are relatively well preserved through the critical interval, so that one cannot test whether the change in composition of the diatom assemblage is correlated to the isotopic shift. If this proves to be the case, the compositional change could be used as an easy and fast indicator of the global cooling and stratification event near the Eocene/Oligocene boundary, and as such it might help in stratigraphic correlation.

\section{TAXONOMIC LIST}

All genera and species found in the sections investigated are listed in alphabetical order. For a discussion of the stratigraphic range and stratigraphic value of each species see Fenner, 1982. References given are for a description of the figure. Synonyms are mentioned only when they are still used. For a comprehensive list of synonyms see Mills (1933-1935) and VanLandingham (1967-1979).

For comparison, slides of samples from Moron and Nankoori, Nicobar Islands, generously provided by the British Museum (Natural History), were examined. From the same samples, Cestodiscus pulchellus and $C$. stokesianus were described by Greville. These species are illustrated in Plates 1 and 2. 
Table 3. (Continued).

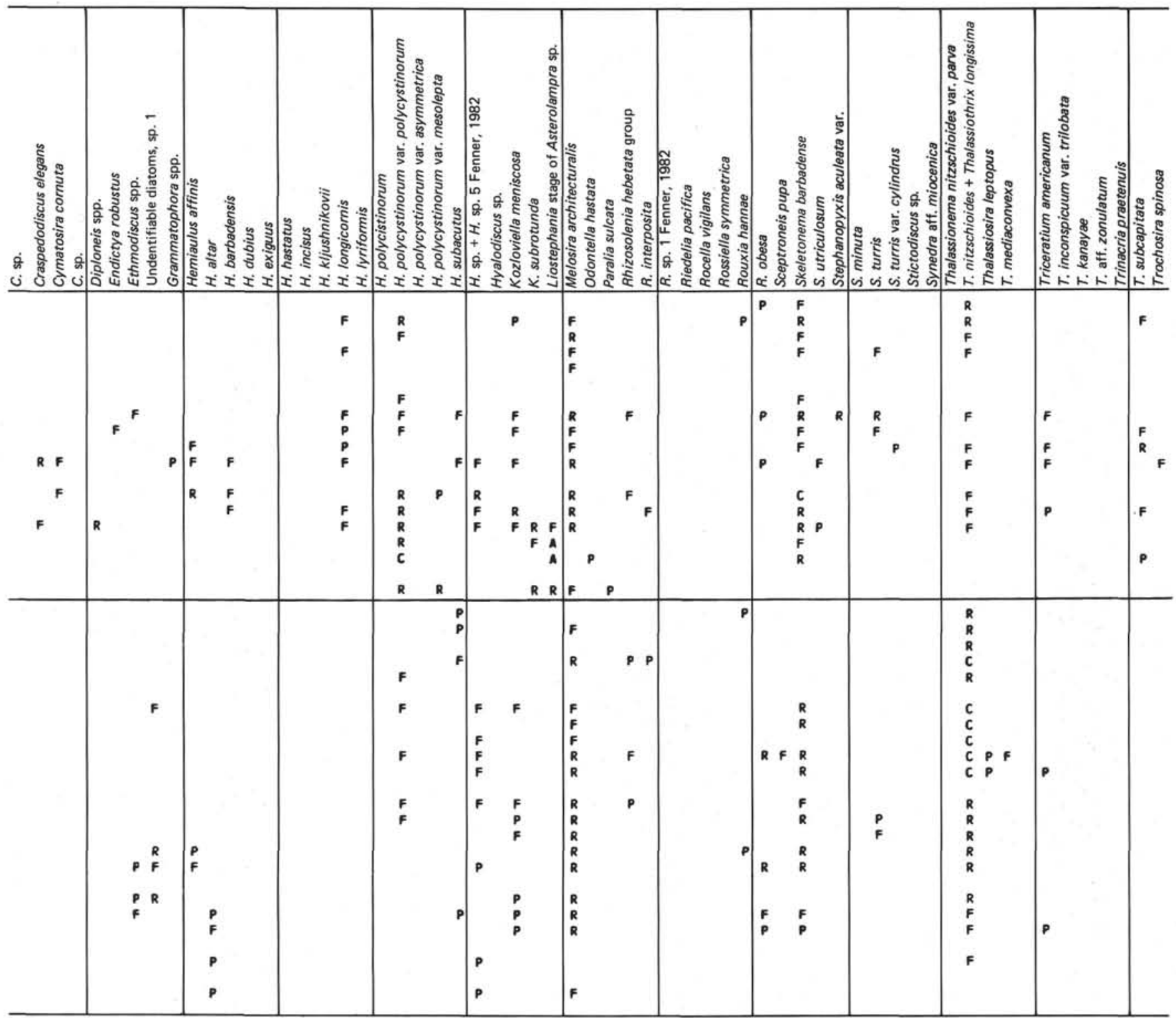

Genus ACTINOCYCLUS Ehrenberg, 1837

Actinocyclus ellipticus Grunow, in Van Heurck, 1883. Synonym: Actinocyclus ellipticus var. elongatus (Grunow) Kolbe, 1954, p. 20, pl. 3, figs. 28, 31. Hustedt, 1930, p. 533, fig. 303; Van Heurck, 1883 , pl. 124 , fig. 10.

Actinocyclus ingens Rattray, 1890. Kanaya, 1959, pp. 97-99, pl. 8, figs. 1-4; Kanaya, 1971, p. 554, pl. 40, figs. 1-8; Schrader, 1973, p. 701 , pl. 18, figs. 1-4, 7 .

Actinocyclus ehrenbergii var. tenella (Breb.) Hustedt, 1930 (Plate 2, Figs. 1-3). Hustedt, 1930, pp. 530-533, fig. 302.

Remarks. The valve outline is circular. The valve face is flat. The areolae are arranged in 4 to 6 sectors, which are separated from each other by radial rows of areolae running from the center to the margin. Within each sector the areolae are arranged in straight rows parallel to the middle row, which, like the sector-dividing rows of areolae, reach from the center of the valve to the margin. Each of the sector-dividing rows ends at the margin with a labiate process. In one of the sectors a pseudocellus is present at the border between the valve face and the margin. The size of the areolae on the valve face is almost constant, but varies with the valve size, there being 9-11 areolae in $10 \mu \mathrm{m}$. On the margin, there are 15 areolae in $10 \mu \mathrm{m}$.
Actinocyclus octonarius Ehrenberg, 1837. Hustedt, 1930, pp. 525-528, fig. 289, as A. ehrenbergii Ralfs, in Pritchard.

\section{Genus ACTINOPTYCHUS Ehrenberg, 1841}

Actinoptychus intermedius A. Schmidt, 1886, in A. Schmidt, et al. 1874-. A. Schmidt et al., 1874-, pl. 91, fig. 3, pl. 109, fig. 12. Actinoptychus senarius Ehrenberg, 1837. Hustedt, 1930, pp. 475-478, fig. 264, as A. undulatus (Bailey) Ralfs, in Pritchard, 1861.

Remarks. There was no attempt to determine accurately all "senarius-like" species of Actinoptychus, so that this name comprises all Actinoptychus species that have six alternatively raised or depressed sectors and no special structures as, for instance, hyaline fields, lines, or a hyaline marginal ring.

Actinoptychus stella Schmidt, 1886, in A. Schmidt et al., (1874-). A. Schmidt et al., 1874-, pl. 90, figs. 1-3; pl. 132, fig. 23.

\section{Genus ARACHNOIDISCUS Deane, ex Pritchard, 1852}

\section{Arachnoidiscus spp.}

Remarks. Single specimens belonging to this group occur only very sporadically. Recent species of this genus are known to be littoral (Hustedt, 1930). 


\section{J. FENNER}

Table 3. (Continued).

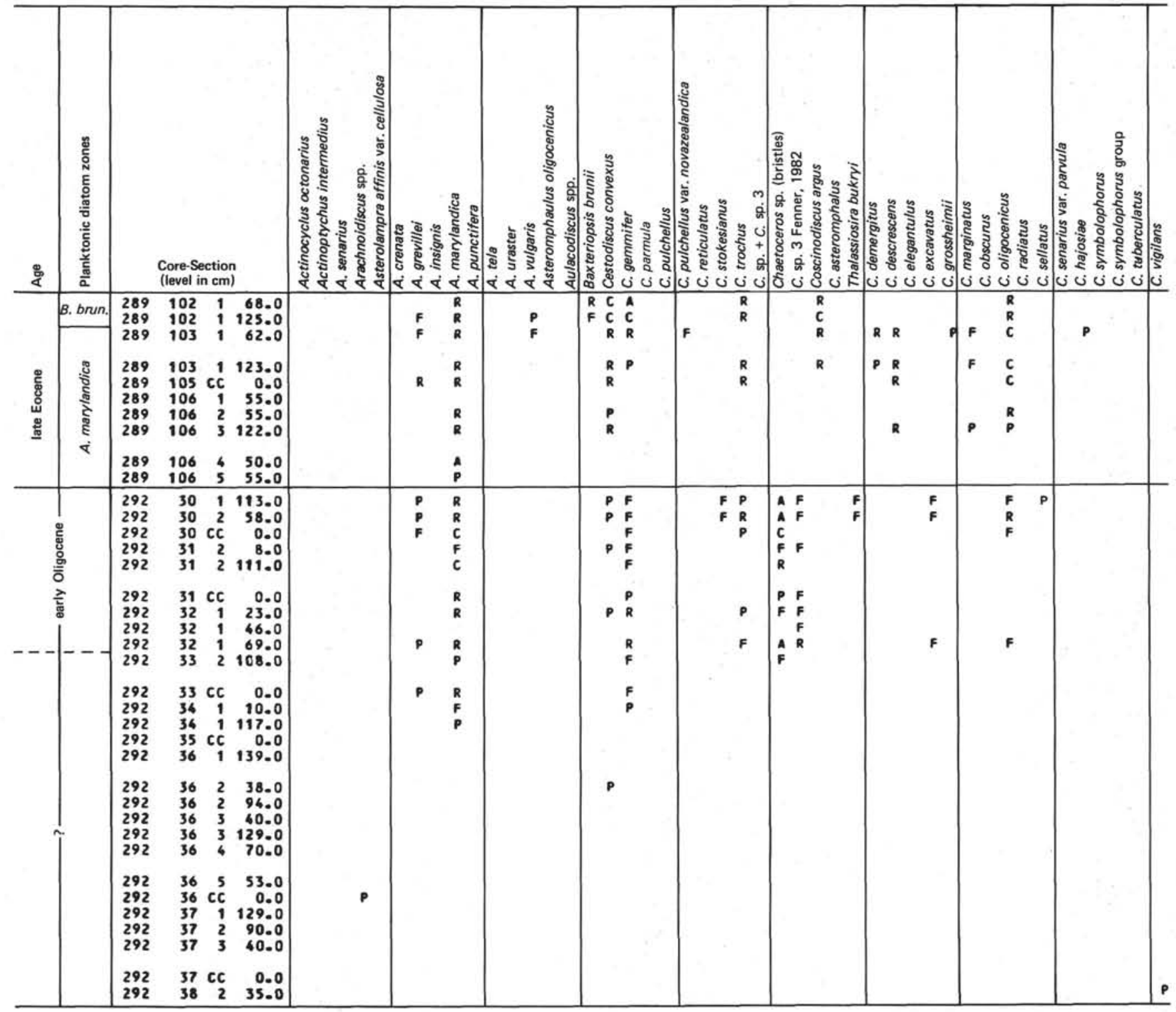

Genus ASTEROLAMPRA Ehrenberg, 1844

Asterolampra affinis Greville var. cellulosa Forti, 1912. Synonyms: Asterolampra schmidtii Hajos, 1976, p. 827, pl. 21, fig. 6; Asterolampra decora Greville sensu Jouse, 1977, pl. 49, fig. 7. Forti, 1913 , p. 1566 , pl. 3, figs. $3,11$.

Asterolampra crenata Greville, 1862. Greville, 1862d, p. 47, pl. 8, figs. 4-16.

Asterolampra grevillei (Wallich) Greville, 1860. Hustedt, 1930, p. 489, fig. 274 .

Asterolampra aff. grevillei (Wallich) Greville, 1860. This species differs from Asterolampra grevillei by having central mashes.

Asterolampra insignis A. Schmidt, 1889, in A. Schmidt et al. (1874-). A. Schmidt et al. (1874-), pl. 137, figs. 1-3.

Asterolampra marylandica Ehrenberg, 1844. Hustedt, 1930, pp. 485-487, fig. 271.

Asterolampra punctifera (Grove) Hanna, 1927. Synonym: Asterolampra affinis Greville var. punctifera Grove, 1896, in A. Schmidt et al. (1874-), pl. 202, fig. 18. Hanna, 1927, p. 109, pl. 17, fig. 3.

Asterolampra tela Gombos, in Gombos and Ciesielski, 1983. Gombos and Ciesielski, 1983, pl. 3, figs. 1-4.

Asterolampra uraster Grove and Sturt, 1889. Grove and Sturt, 1889, p. 143, pl. 13, fig. 42; Gombos, 1980, p. 239, fig. 19.
Asterolampra vulgaris Greville, 1862. Greville, 1862d, p. 47, pl. 7, fig. 17-25.

Genus ASTEROMPHALUS Ehrenberg, 1845

Asteromphalus oligocenicus Schrader and Fenner, 1976. Synonym: Asterolampra rotula Greville sensu Jousé, 1977, pl. 55, fig. 14. Schrader and Fenner, 1976, p. 965, pl. 21, figs. 13-14; pl. 28, fig. 1 .

Asteromphalus imbricatus Wallich, 1860. Ralfs, in Pritchard, 1861, p. 837 .

\section{Genus AULACODISCUS Ehrenberg, 1844}

Aulacodiscus spp.

Remarks. Exact determination to the species level was not attempted. All observed specimens of this predominantly littoral genus are listed under Aulacodiscus spp., and are used as environmental indicators.

Genus AULACOSIRA (AULACOSEIRA) Thwaites, 1848 Aulacosira granulata (Ehrenberg) Simonsen, 1979. Hustedt, 1930, pp. 248-252, figs. 104-105. 
Table 3. (Continued).

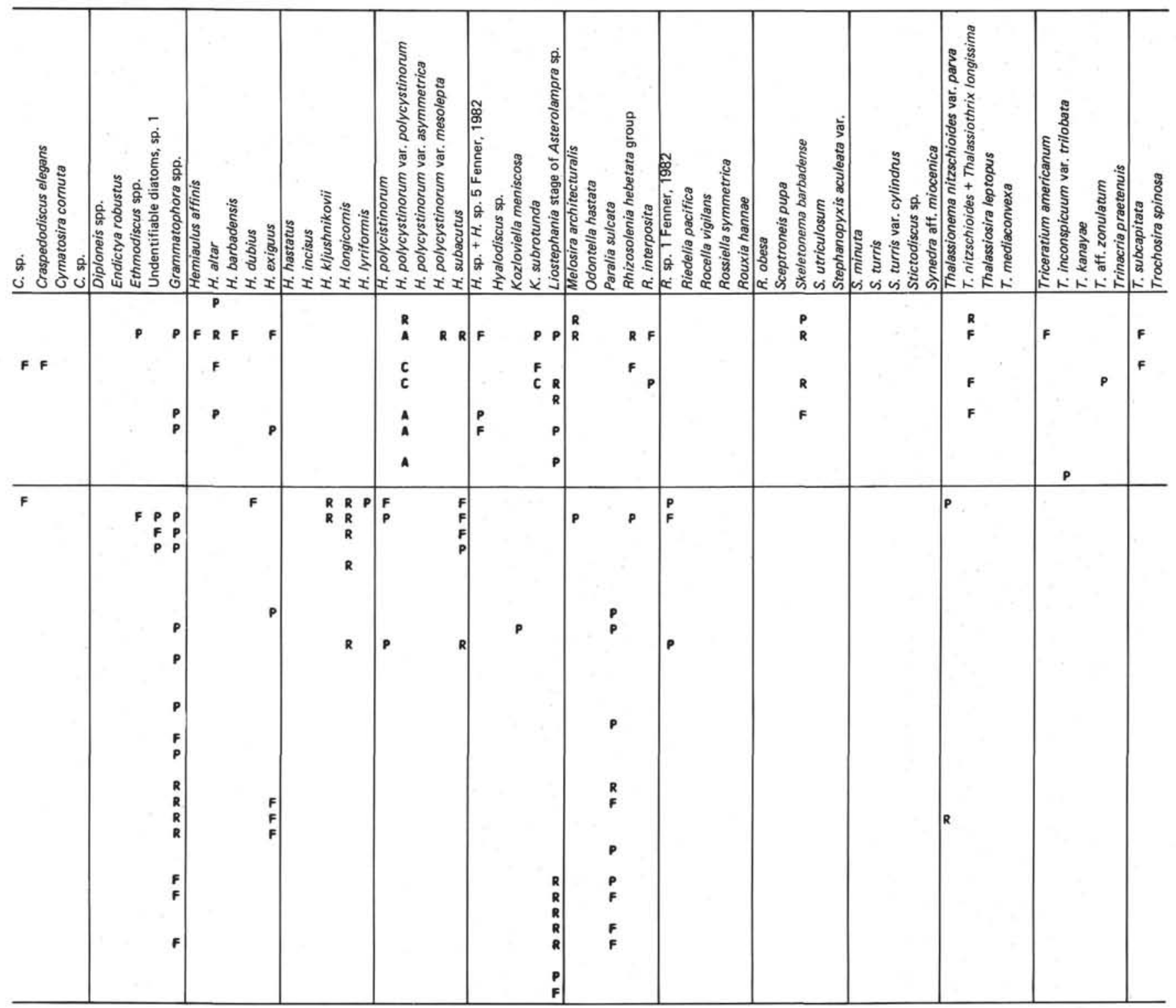

Remarks. This planktonic freshwater species is displaced in marine sediments.

\section{Genus AULISCUS Ehrenberg, 1843}

Auliscus spp.

Remarks. Only a single specimen belonging to this genus was found in the middle Eocene of Site 357.

\section{Genus BAXTERIOPSIS Karsten, 1928}

Baxteriopsis brunii (Van Heurck) Karsten, 1928. Van Heurck, 1896, p. 460 , fig. 190 .

\section{Genus BIDDULPHIA Gray, 1821}

Biddulphia tridens Ehrenberg, 1840. Synonym: Biddulphia tuomeyi (Bailey) Roper, 1859, p. 8, pl. 1, figs. 1-2. Hustedt, 1930, pp. 834-836, fig. 491.

Genus BOGOROVIA Jousé, 1973

Bogorovia veniamini Jousé, 1973. Jousé, 1973, p. 351, pl. 4, figs. 1-3.

\section{Genus BRIGHTWELLIA Ralfs, in Pritchard, 1861}

Brightwellia spp.

Remarks. Only fragments of species belonging to this genus were found in the middle Eocene of Site 357; these did not allow further determination.

\section{Genus CESTODISCUS Greville, 1865}

Cestodiscus convexus Castracane, 1886. Synonym: Cestodiscus pulchellus Greville sensu Jousé, 1973, pp. 345, 348, pl. 1, figs. 12-13. Castracane, 1886, p. 123, pl. 7, fig. 6; Fenner, 1982, p. 86, pl. 13, figs. 1-3.

Cestodiscus gemmifer Castracane, 1886. Synonym: Cestodiscus aff. superbus sensu Jousé, 1973, pl. 1, fig. 11. Castracane, 1886, p. 124, pl. 2, fig. 7; pl. 7, fig. 7; Fenner (1982), p. 86, pl. 12, figs. $1-4$.

Cestodiscus parmula Castracane, 1886. Synonym: Cestodiscus sp. 2 Fenner, 1982, p. 89, pl. 14, figs. 3-4. Castracane, 1886, p. 125, pl. 7, fig. 5.

Cestodiscus pulchellus Greville, 1866. (Plate 1, Figs. 1-4.) Synonym: ?Coscinodiscus superbus Hardmann (ms) in Rattray, 1889, p. 458. Greville, 1866, p. 123, pl. 11, fig. 5. 
Table 4. Diatom species occurrences in Eocene and Oligocene samples from 73, central equatorial Pacific.

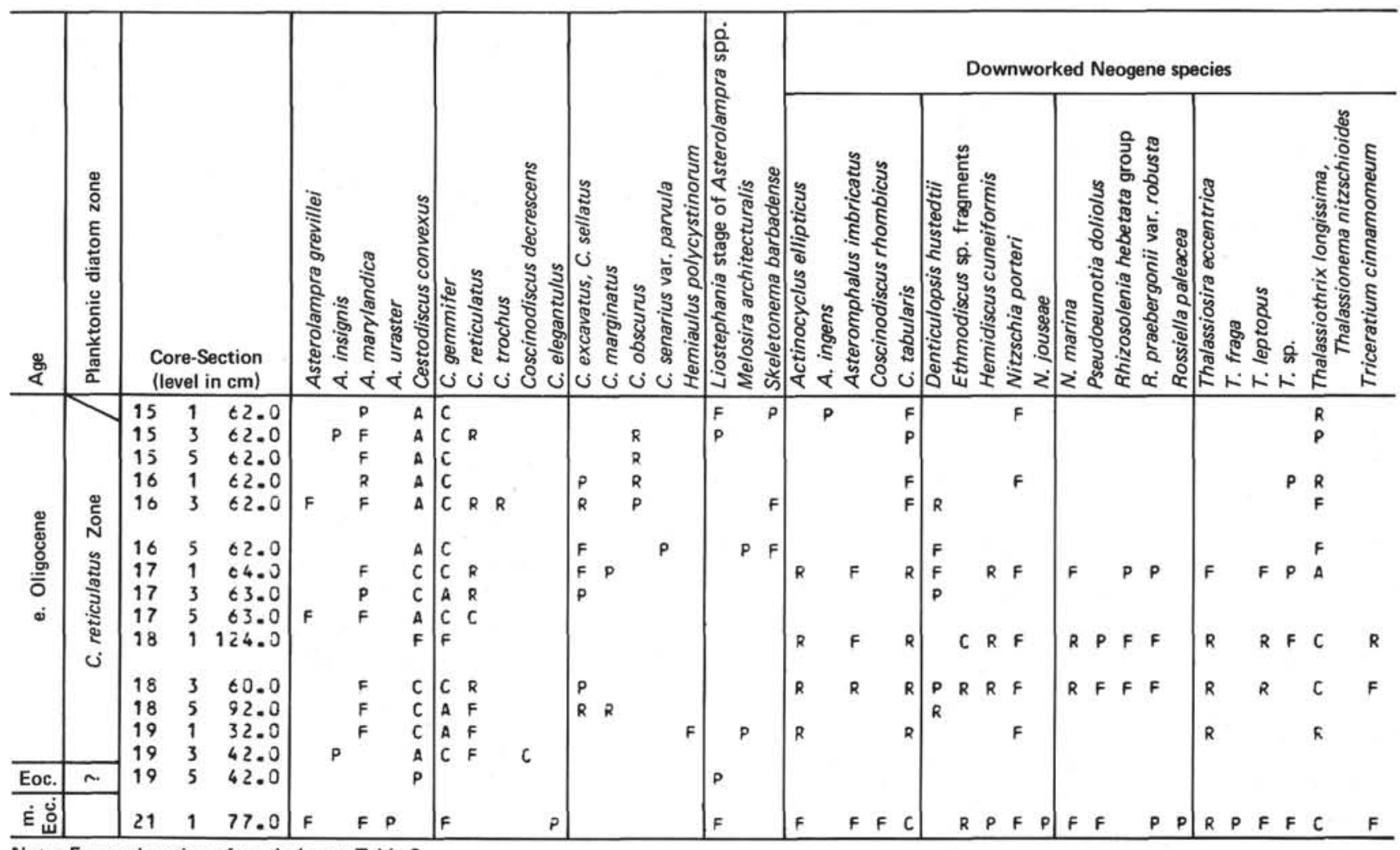

Note: For explanation of symbols, see Table 2.

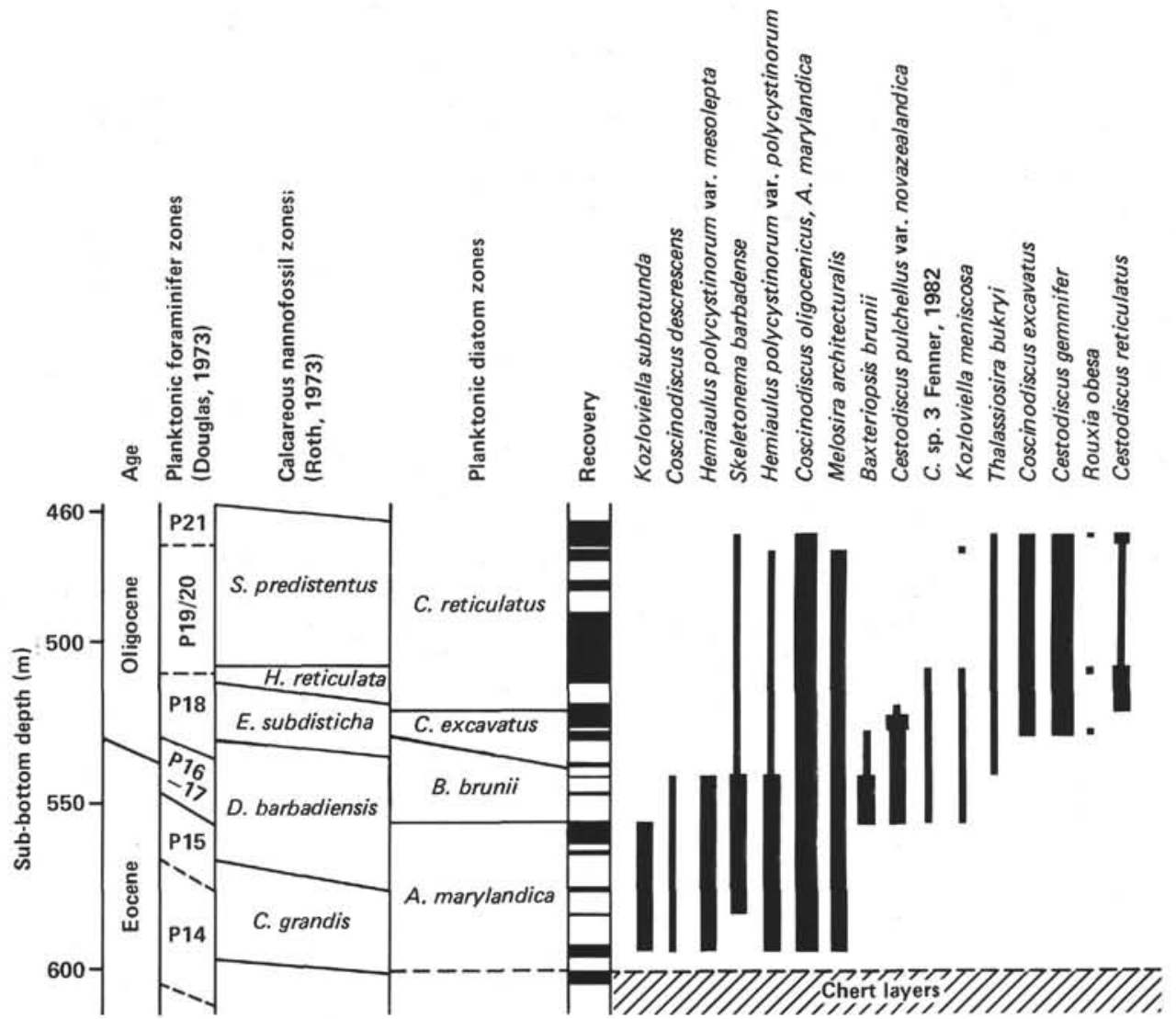

Figure 5. Ranges of stratigraphically important diatom species in middle Eocene to middle Oligocene cores of DSDP Site 167, central equatorial Pacific. Relative abundance as in Figure 3. 


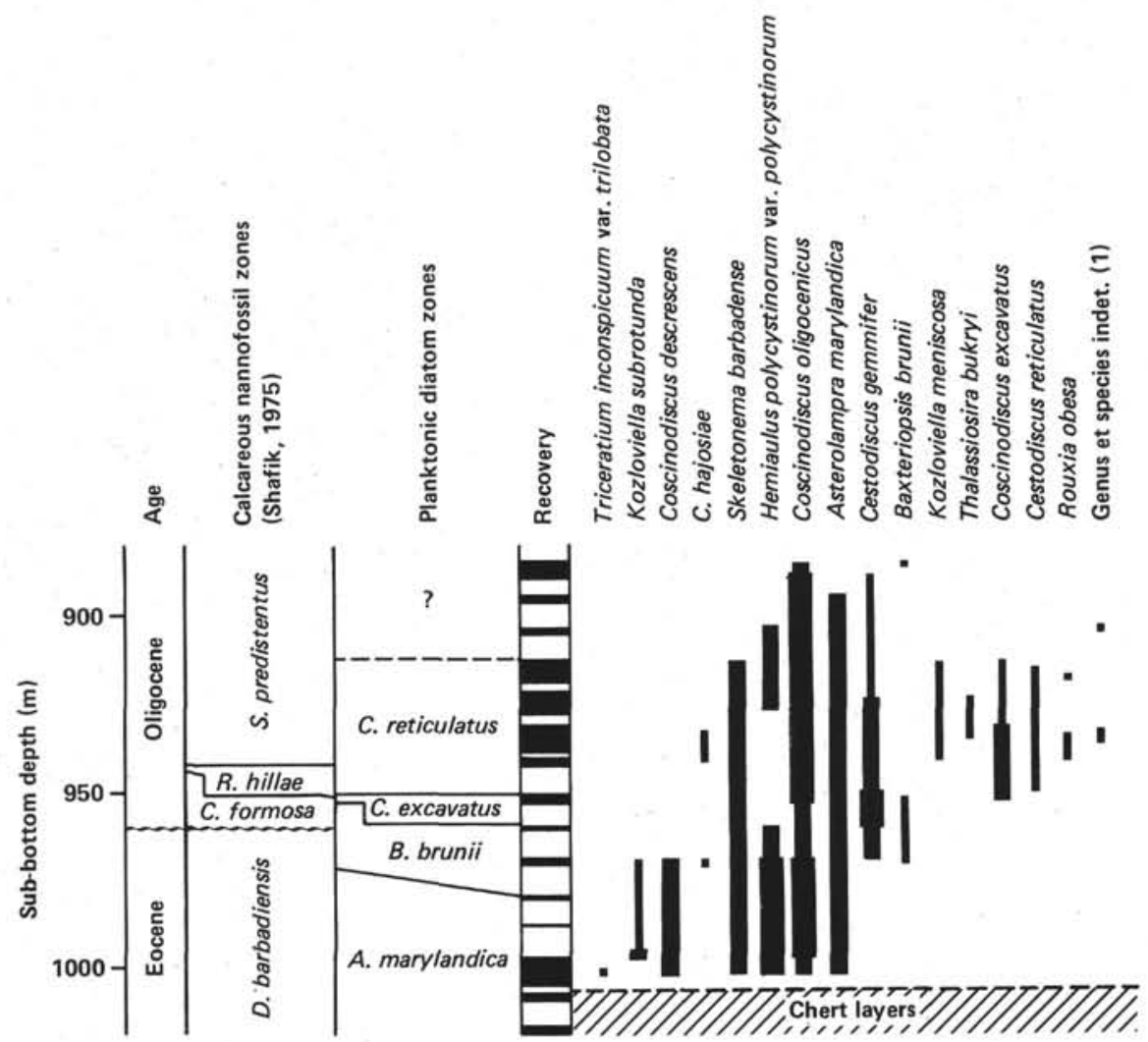

Figure 6. Ranges of stratigraphically important diatom species in late Eocene to early Oligocene cores of DSDP Site 289, Ontong-Java Plateau. Relative abundance as in Figure 3.

Remarks. Greville (1866) gave an accurate description of this species, but later misuse of the species name led to confusion. For a detailed description see Fenner, 1982, p. 86, pl. 15, figs. 1-4. Here the paratypes from slides of Greville's collection are illustrated.

Cestodiscus pulchellus Greville var. novazealandica Grove, 1890, in

A. Schmidt et al., 1874-. Synonyms: Coscinodiscus novazealandicus Hanna, 1932, pp. 182-183, pl. 9, fig. 3; Cestodiscus spinifer Grove and Sturt sensu Fenner, 1982, p. 88, pl. 15, fig. 5. A. Schmidt et al. (1874-), pl. 148, fig. 7; pl. 163, figs. 8, 10?; Fenner, 1982, p. 87 , pl. 12, figs. 5-7.

Remarks. Very large specimens with valve face slightly concentrically undulated are common around the Eocene/Oligocene boundary. Cestodiscus reticulatus Fenner, in press. Synonym: Coscinodiscus superbus Hardmann sensu Fenner, 1977, p. 516, pl. 14, figs. 2-3, not figs. 1, 4. Fenner, 1982, p. 87, pl. 14, figs. 1-2.

Cestodiscus stokesianus Greville, 1866. (Plate 1, Figs. 6-8.) Greville, 1866 , p. 123 , pl. 11 , fig. 4 ; Fenner, 1982 , p. 88 , pl. 14 , figs. $7-8$. Description. The valve outline is circular. The valve face is convex and densely areolated, with the areolae decreasing in size from the center (11 areolae in $10 \mu \mathrm{m})$ to the margin $(\sim 20$ areolae in $10 \mu \mathrm{m})$. The areolae are arranged in 4-6 sectors, within which rows of areolae run parallel to the longest row of areolae in the fascicle, which is the middle row of each fascicle. The fascicles are separated from each other by a long radial row of areolae running from the centre of the valve face to the margin, where they end in a labiate process.

Stratigraphic occurrence. This species is found from the late Eocene to the middle Miocene.

Cestodiscus trochus Castracane, 1886. (Plate 1, Fig. 3-4.) Synonym: Cestodiscus mukhinae Jousé, 1973, pp. 344-345, pl. 1, figs. 1-5. Castracane, 1886, p. 123, pl. 7, figs. 1, 3; Fenner, 1982, p. 88, pl. 14 , fig. 5 .

Cestodiscus sp. 1 Fenner, 1982. Synonym: Cestodiscus aff. pulchellus Jousé, 1973, pl. 1, figs. 9-10, not fig. 11. Fenner, 1982, p. 88, pl. 14, fig. 6 .

Cestodiscus sp. 3 Fenner, 1982. Fenner, 1982, p. 89, pl. 11, figs. 3-5.
Genus CHAETOCEROS Ehrenberg, 1844

Chaetoceros sp. (1) Fenner, 1982. Fenner, 1982, p. 89, pl. 32, figs. 15-16.

Chaetoceros sp. (3) Fenner, 1982. Fenner, 1982, p. 89, pl. 32, fig. 18. Chaetoceros bristles.

Remarks. Under this category undifferentiated types of Chaetoceros bristles are listed.

\section{Genus CLADOGRAMMA Ehrenberg, 1854}

Cladogramma conicum Greville var. campanulatum Forti, in Tempère and Peragallo, 1907-1915. Forti, 1913, p. 1563, pl. 3, figs. 2, 4, 7.

\section{Genus CLAVULARIA Greville, 1865}

Clavularia barbadensis Greville, 1865. Synonyms: Clavularia catenata Brun, 1896, p. 236, pl. 20, figs. 12-13; Cymatosira sp. 1 Fenner, 1977 , p. 518, pl. 32, figs. 2-5. Greville, 1865a, p. 24, pl. 3, figs. 1-3; Fenner, 1982, p. 90, pl. 28, figs. 9-12.

\section{Genus COCCONEIS Ehrenberg, 1838}

Cocconeis spp.

\section{Genus COSCINODISCUS Ehrenberg, 1838}

Coscinodiscus argus Ehrenberg, 1838. Hustedt, 1930, pp. 422-424, fig. 226.

Coscinodiscus asteromphalus Ehrenberg, 1844. Hustedt, 1930, pp. 452-454, fig. 250.

Coscinodiscus demergitus Fenner, ' 77 . Fenner, 1977, p. 514, pl. 4, Figs. 1-3; Fenner, 1982, p. 92.

Coscinodiscus descrescens Grunow, 1878, in A. Schmidt et al., 1874-. A Schmidt et al. (1874-), pl. 61, figs. 7-9; Fenner, 1982, p. 92 , pl. 9 , fig. 7 .

Coscinodiscus elegantulus Greville, 1861. Greville, 1861a, p. 42, pl. 4, fig. 8; Fenner, 1982, p. 92, pl. 9, fig. 4. 
Table 5. Diatom species occurrences in Eocene and Oligocene samples from Sites 216 and 217, Ninetyeast Ridge.

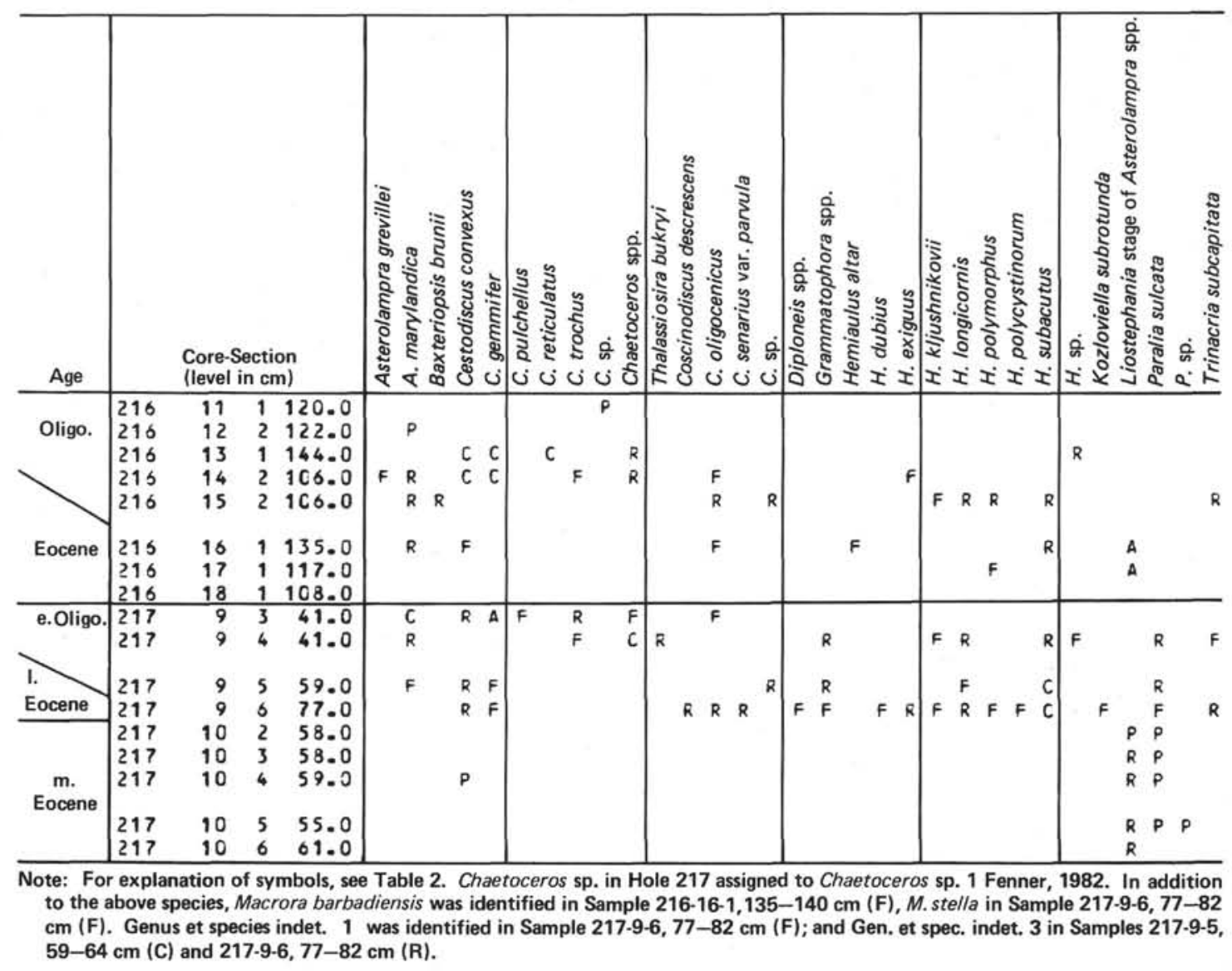

Table 6. Diatom species occurrences in Eocene samples from Site 220, Arabian Basin.

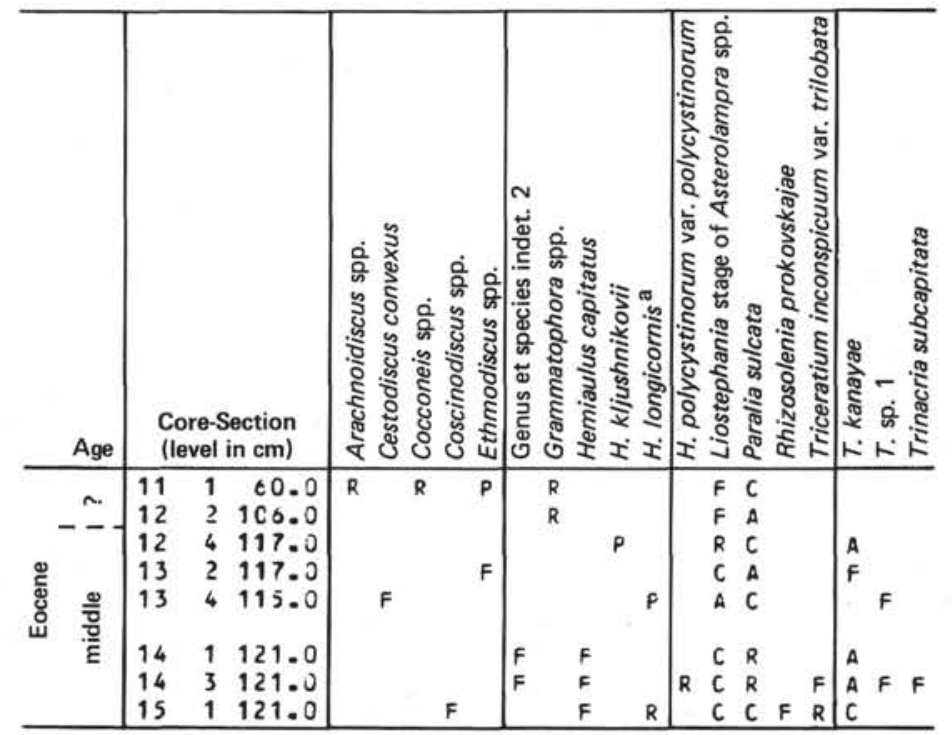

Note: For explanation of symbols, see Table 2. Undifferentiated benthic diatoms were found in Samples 220-11-1, 60-65 cm (C), 220-12-2, 106-111 cm (C), 220 $13-2,117-122 \mathrm{~cm}$ (F), 220-13-4, 115-120 cm (F), 220-15-1, 121-126 cm (F).

a Sample 220-15-1, $121 \mathrm{~cm}$ is $H$. aff. longicornis. 
Coscinodiscus excavatus Greville, 1861. Synonym: Coscinodiscus diophthalamus Castracane, 1886, p. 163, pl. 16, fig. 4. Greville ms., Ralfs in Pritchard, 1861, p. 829, pl. 8, fig. 26; Grunow, 1884, p. 73; Fenner, 1982, p. 93.

Coscinodiscus extravagans A. Schmidt, 1878, in A. Schmidt et al., 1874-. Synonym: ?Tripodiscus beringensis Mann, 1907, p. 278, pl. 50, fig. 6. A. Schmidt et al., 1874-, pl. 58, fig. 33; Fenner, 1982 , p. 93 , pl. 16, fig. 6 .

Coscinodiscus grossheimii Gleser, in Sheshukova-Poretzkaya and Gleser, 1962. Sheshukova-Poretzkaya and Gleser, 1962, p. 178, pl. 1 , figs. $5 \mathrm{a}-\mathrm{b}$.

Coscinodiscus hajosiae Fenner, in press. Synonyms: Podosira aff. maxima Dzinoridze et al., 1978, pl. 4, figs. 6-7; Hyalodiscus ambiguus Grun sensu Paramonora, 1964, pl. 2, fig. 2; Coscinodiscus spiralis Karsten, 1905, p. 81, pl. 5, figs. 5a-b. Fenner, in press, pl. 2, fig. 1; Fenner, 1982, p. 96, pl. 8, fig. 3.

Coscinodiscus lewisianus Greville, 1866. Greville, 1866b, p. 78, pl. 8, figs. 8-10.

Coscinodiscus marginatus Ehrenberg, 1841. Hustedt, 1930, p. 416, fig. 223.

Coscinodiscus nodulifer A. Schmidt, 1878, in A. Schmidt et al., 1874-. Hustedt, 1930, pp. 426-427, fig. 229.

Coscinodiscus obscurus A. Schmidt, 1878, in A. Schmidt et al., 1874-. A. Schmidt et al., 1874-, pl. 61, figs. 16-17.

Coscinodiscus oligocenicus Jousé, 1973. Jousé, 1973, p. 348, pl. 1, figs. 6-8, 16; Fenner, 1977, pp. 515-516, pl. 4, figs. 5-10; Fenner, 1982, p. 95 , pl. 9 , fig. 8.

Coscinodiscus payeri Grunow, 1884. Grunow, 1884, p. 80, pl. 3(C), figs. 12-13.

Coscinodiscus radiatus Ehrenberg, 1839. Hustedt, 1930, pp. 420-421, fig. 225.

Coscinodiscus rhombicus Castracane, 1886. Synonyms: Coscinodiscus lanceolatus Castracane, 1886, p. 164, pl. 17, fig. 19; Coscinodiscus? naviculoides Truan y Luard and Witt, 1888, p. 14, pl. 2 , fig. 10; Coscinodiscus punctatus Ehrenberg var. rhombica Rattray, 1889 , p. 547 . Castracane, 1886, p. 164, pl. 22, fig. 11.

Coscinodiscus sellatus Jousé, 1973. Jousé, 1973, pp. 348-349, pl. 2, figs. 2-4.

Remarks. Although I consider this "species" to be a variety of $C$.

excavatus, it was treated separately to investigate possible differences in its stratigraphic range.

Coscinodiscus senarius var. parvula A. Schmidt, in Tempère and Peragallo, 1912. Synonym: Coscinodiscus senarius A. Schmidt sensu Dzinoridze et al., 1976, pp. 42-43, figs. 57-61. Tempère and Peragallo, 1912, p. 344, no. 701-726; Fenner, 1982, p. 96, pl. 5, fig. 3.

Coscinodiscus symbolophorus Group. Fenner, 1982, p. 96, pl. 4, fig. 2.

Coscinodiscus tabularis Grunow, 1884. Synonyms: Coscinodiscus endoi Kanaya, 1959, pp. 76-77, pl. 3, figs. 8-11; Coscinodiscus nodulifer sensu McCollum, 1975, p. 527, pl. 5, figs. 7-8. Hustedt, 1958, pp. 119-120, figs. 48-56; Fenner et al., 1976, p. 774, pl. 7, figs. 10-13; Fenner, 1977, p. 516.

Coscinodiscus tuberculatus Greville, 1861. Greville, 1861a, p. 42, pl. 4, fig. 6; Fenner, 1982, p. 96, pl. 9, figs. 1-3.

Coscinodiscus vigilans A. Schmidt, 1888, in A. Schmidt et al., 1874-. A. Schmidt et al., 1874-, pl. 114, fig. 11.

\section{Genus CRASPEDODISCUS Ehrenberg, 1844}

Craspedodiscus elegans Ehrenberg, 1844. Synonym: Craspedodiscus coscinodiscus Ehrenberg, 1844, p. 266. Ehrenberg, 1844, p. 266, fig. 12; Fenner, 1982, p. 97.

Craspedodiscus oblongus (Greville) A. Schmidt, 1886, in A. Schmidt et al., 1874-. Synonym: Porodiscus oblongatus Greville, 1863b, p. 65 , pl. 4, fig. 5. Greville, 1866a, p. 4, pl. 1, figs. 9-10.

\section{Genus CYMATOSIRA Grunow, 1862}

Cymatosira aff. cornuta Schrader and Fenner, 1976. Schrader and Fenner, 1976, p. 976, pl. 8, fig. 6; pl. 22, fig. 14; Fenner, 1982, p. 99 , pl. 31 , fig. 8 .

\section{Genus DENTICULOPSIS Simonsen, 1979}

Denticulopsis hustedtii (Simonsen and Kanaya) Simonsen, 1979. Synonym: Denticula hustedtii Simonsen and Kanaya, 1961, p. 501, pl.
1, figs. 19-25; pl. 2, figs. 36-47. Simonsen and Kanaya, 1961, p. 501 , pl. 1, figs. 19-25; pl. 2, figs. 36-47.

\section{Genus DIPLONEIS Ehrenberg, 1840}

Diploneis spp.

Remarks. Species of this genus are of shallow-water origin.

\section{Genus ENDICTYA Ehrenberg, 1845}

Endictya robustus (Greville) Hanna and Grant, 1926. Hanna and Grant, 1926, p. 144, pl. 16, figs. 2-3.

\section{Genus ETHMODISCUS Castracane, 1886}

\section{Ethmodiscus spp.}

Remarks. Only fragments of specimens interpreted as belonging to the genus Ethmodiscus have been found.

\section{Genus et species indet. 1. (Plate 2, Fig. 8. .)}

Description. The valve outline is quadrangular, with robust horns at each corner. The valve length is $50-55 \mu \mathrm{m}$. One horn is always thinner and generally broken, the other three are of equal width $(8-10 \mu \mathrm{m})$ from base to top and end in a stout, triangular spine. Thin marginal ridges run along the valve margin and connect the horns. The valve face, mantle, and horns are equally coarsely areolated (4-5 areolae in $10 \mu \mathrm{m})$.

Stratigraphic occurrence. This species is found in the middle Oligocene (S. distentus Zone) of Sites 292 and 289.

Genus et species indet. 2. (Plate 2, Fig. 5.)

Description. The valve outline is circular. The central part of the valve face is depressed and sharply offset from the outer part of the valve face by a ridge. The areolae are arranged in radial rows. Between the areolae on the outer and inner part of the valve face small nodules are common. The areolation of the inner part is finer ( 5 areolae in $10 \mu \mathrm{m})$ than on the outer part of the valve face (2-3 areolae in $10 \mu \mathrm{m})$.

Stratigraphic occurrence. This species was found in the middle Eocene of Site 220.

\section{Genus GRAMMATOPHORA Ehrenberg, 1839}

\section{Grammatophora spp.}

Remarks. Intercalary bands belonging to species of this genus were found sporadically. These intercalary bands are especially dissolutionresistant.

\section{Genus HEMIAULUS Ehrenberg, 1844}

Hemiaulus affinis Grunow, in Van Heurck, 1883. Van Heurck, 1883, pl. 106, figs. 10-11.

Hemiaulus alatus Greville, 1865. Greville, 1865b, p. 31, pl. 3, fig. 14; Fenner, 1977, p. 529, pl. 26, figs. 1-2.

Hemiaulus altar Brun, 1896. Brun, 1896, p. 238, pl. 20, fig. 19-20.

Remarks. In cores with poor preservation, so that only broken arms but no complete valves could be found, differentiation between $H$. altar and $H$. longicornis was not possible.

Hemiaulus barbadiensis Grunow, 1884. Grunow, 1884, p. 63; Fenner, 1982 , p. 103 , pl. 23, fig. 4

Hemiaulus capitatus Greville, 1865. Greville, 1865, p. 54, pl. 6, fig. 24. Hemiaulus dubius Grunow, 1884. Synonym: Hemiaulus biharensis Pantocsek, 1892, p. 57, pl. 38, figs. 528-529. Grunow, 1884, p. 61, pl. 5 (E), fig. 54; Fenner, 1982, pp. 103, 104, pl. 26, figs. 1-5.

Hemiaulus exiguus Greville, 1865. Greville, 1865a, p. 29, pl. 4, fig. 20 Hemiaulus incisus? Hajós, 1976. Hajos, 1976, p. 829, pl. 23, figs. 4-9. Remarks. Only fragments-parts of horns-were found. Thus the assignments of these fragments to this species stands on very weak grounds.

Hemiaulus kljushnikovii Gleser, in Sheshukova-Poretzkaya and Gleser, 1964. Sheshukova-Poretzkaya and Gleser, 1964, p. 87, pl. 3 , fig. 8; Fenner, 1977, p. 521, pl. 25, figs. 12, 14-15.

Hemiaulus longicornis Greville, 1865. Synonym: Riedelia longicornis (Greville) Schrader and Fenner, 1976, p. 997. Greville, 1865a, p. 31 , pl. 3, fig. 13 .

Hemiaulus aff. longicornis Greville, 1865

Remarks. This species differs from $H$. longicornis by its smaller size, relatively wider horns, and less dense areolation. It is found in the lower Eocene and lower middle Eocene at Sites 149 and 220. 
Hemiaulus lyriformis Greville, 1865. Synonym: Riedelia lyriformis (Greville) Schrader and Fenner, 1976, p. 997. Greville, 1865a, p. 30 , pl. 3 , fig. 11 .

Hemiaulus polycystinorum Ehrenberg var. polycystinorum Grunow, 1884. Grunow, 1884, p. 65; Cleve-Euler, 1951, p. 125; A. Schmidt et al., 1874-, pl. 143, figs. 24?, 28; Fenner, 1982, p. 106, pl. 20, figs. 2-5.

Hemiaulus polycystinorum Ehrenberg var. dissona Fenner, 1977. Fenner, 1977, p. 521, pl. 22, figs. 14-16.

Hemiaulus polycystinorum Ehrenberg var. mesolepta Grunow, 1884. Grunow, 1884, p. 65, pl. 2 (B), fig. 43.

Hemiaulus subacutus Grunow, 1884. Grunow, 1884, p. 61, pl. 5 (E), fig. 55; Fenner, 1982, p. 107, pl. 18, figs. 2-10.

Hemiaulus taurus Gombos, in Gombos and Ciesielski, 1983. Gombos and Ciesielski, 1983, pl. 19, figs. 1-8.

Hemiaulus sp. 5 Fenner, 1982. Fenner, 1982, p. 108, pl. 23, fig. 5.

\section{Genus HEMIDISCUS Wallich, 1860}

Hemidiscus cuneiformis Wallich, 1860. Hustedt, 1930, p. 904, fig. 542; Fenner, 1977, p. 523, pl. 1, fig. 1.

\section{Genus HYALODISCUS Ehrenberg, 1845}

Hyalodiscus spp.

Remarks. Specimens belonging in this genus were found extremely rarely, and there was no attempt to determine the species.

Genus KOZLOVIELLA Jousé, 1973

Kozloviella meniscosa Fenner, 1982. Fenner, 1982, p. 112, pl. 17, figs. 3-4.

Kozloviella subrotunda Fenner, in press. Fenner, 1982, pp. 112-113, pl. 17, figs. 1-2.

Liostephania stage of Asterolampra spp. Hanna and Brigger, 1970, pp. $89-100$.

\section{Genus LISITZINIA Jousé, 1978}

Lisitzinia ornata Jousé, 1978. Synonym: Triceratium aff. zonulatum (Greville), Sheshukova-Poretzkaya et al., 1967, pl. 37, fig. 2; Triceratium cruciforme (A.S.) sensu Schrader and Fenner, 1976, p. 1002 , pl. 27, fig. 2. Jouse, 1978, pp. 47-48, pl. 10, figs. 1-6.

\section{Genus MELOSIRA Agardh, 1824}

Melosira architecturalis Brun, 1892. Synonym: Cyclotella hannae Kanaya, 1957, pp. 82-84, pl. 3, figs. 10-14. Brun, in Schmidt et al., 1874-, pl. 177, fig. 45-50.

\section{Genus NAVICULA Bory, 1822}

Navicula spp.

Remarks. No species were determined for the single specimens belonging to this genus.

\section{Genus NITZSCHIA Hassall, 1845}

Nitzschia jouseae Burckle, 1972. Burckle, 1972, p. 240, pl. 2, figs. 17-21.

Nitzschia marina Grunow, in Cleve and Grunow, 1880. Cleve and Grunow, 1880 , p. 70 .

Nitzschia porteri Frenguelli, 1949. Frenguelli, 1949, p. 116, pl. 1, figs. 33-34.

Genus ODONTELLA Agardh, 1832

Odontella hastata (Greville) Fenner, 1982. Greville, 1865a, p. 31, pl 3, fig. 15; Fenner, 1982, p. 115, pl. 23, figs. 6-7.

\section{Genus PARALIA Heiberg, 1863}

Paralia sulcata (Ehrenberg) Cleve, 1873. Synonym: Melosira sulcato (Ehrenberg) Kützing, 1844, p. 55. Hustedt, 1930, pp. 276-278, figs. 118-120.

\section{Genus PSEUDOEUNOTIA Grunow, in Van Heurck, 1880}

Pseudoeunotia doliolus (Wallich) Grunow, in Van Heurck, 1880. Husted, 1959, pp. 258-260, fig. 737.
Genus PSEUDOPODOSIRA Jousé, in Proshkina-Lavrenko, 1949

\section{Pseudopodosira spp.}

Remarks. No determination to the species level was possible in the few, poorly preserved specimens found.

\section{Genus PYXILLA Greville, 1865}

Pyxilla caput-avis Brun, 1896. Brun, 1896, p. 242, pl. 19, fig. 11. Pyxilla gracilis Tempère and Forti, in Forti, 1909. Synonym: Pyrgupyxis gracilis (Tempère and Forti) Hendey, 1969, p. 5. Forti, 1909, p. 26 , pl. 2, fig. 5 .

Pyxilla reticulata Grove and Sturt, 1887. Synonyms: Pyxilla gracilis var. saratoviana Tempère and Forti, in Forti, 1909, pl. 2, figs. 7-8; not Hemiaulus ?saratovianus Pantocsek, 1889, pl. 13, fig. 235; Pyxilla johnsoniana Forti, 1909, pl. 2, fig. 2; not $P$. johnsoniana Greville, 1865a, p. 2, pl. 1, fig. 6; P. johnsoniana Greville var. corniculum Brun, 1893-1896, p. 243, pl. 19, figs. 12-13; $P$. prolongata Brun, 1893, p. 176, pl. 24, fig. 7; Pyrgupyxis prolongata (Brun) Hendey, 1969, p. 5. Fenner, 1982, p. 119.

\section{Genus RHAPHONEIS Ehrenberg, 184}

Rhaphoneis amphiceros Ehrenberg, 1844. Andrews, 1975, pp. 204205, pl. 1, figs. 9-12.

\section{Genus RHIZOSOLENIA Ehrenberg, 1841}

Rhizosolenia hebetata Group. Grunow, 1884, p. 44, 96, pl. 5, figs. 48-50.

Rhizosolenia interposita Hajós, 1976. Synonym: Rhizosolenia praebarboi Schrader sensu Schrader and Fenner, 1976, p. 997, pl. 7, fig. 10, not pl. 5, fig. 16. Hajós, 1976, p. 827, pl. 21, fig. 8 .

Rhizosolenia prokovskajae (Jousé) Strelnikova, 1974. Strelnikova, 1974 , p. 80 , pl. 28 , figs. $1-9$.

Rhizosolenia praebergonii Muchina var. robusta Burckle and Trainer, 1979. Burckle and Trainer, 1979, Appendix, pl. 1, figs. 1-7.

Rhizosolenia sp. 1 Fenner, 1982. Fenner, 1982, p. 122, pl. 3, figs. 10-12.

Genus RIEDELIA Jousé and Sheshukova-Poretzkaya, 1971

Riedelia pacifica Jousé, in Jousé and Sheshukova-Poretzkaya, 1971. Jousé and Sheshukova-Poretzkaya, 1971, p. 22, pl. 2, figs. 3-4; Gleser and Jousé, 1974, p. 60, pl. 3, fig. 11.

\section{Genus ROCELLA Hanna, 1930}

Rocella gelida (Mann) Bukry, 1978. Synonyms: Stictodiscus gelidus Mann, 1907, p. 268, pl. 50, fig. 5; Rocella gemma Hanna, 1930, in part, p. 415, pl. 40, figs. 1-2, 4-9. Bukry, 1978, p. 788, pl. 5, figs. $1-13$.

Rocella princeps (Jousé) Fenner, 1982. Jousé, 1973, p. 350, pl. 3, figs. 8-12; Fenner, 1982, p. 123.

Rocella schraderi Bukry, 1978. Bukry, 1978, p. 788, pl. 6; figs. 1-10; pl. 7 , fig. 1.

Rocella vigilans Fenner, in press. Fenner, 1982, p. 123, pl. 4, figs. 6-7; pl. 6, fig. 8.

\section{Genus ROSSIELLA Desikachary and Maheshwari, 1958}

Rossiella paleacea (Grunow) Desikachary and Maheshwari, 1958. Synonyms: Stoschia(?) paleacea Grunow, in Van Heurck, 1883, pl. 128, fig. 6; Coscinodiscus paleaceus (Grunow) Rattray, 1889, p. 597; Cussia paleacea (Grunow) Schrader, 1974, p. 543, pl. 1, figs. 11-14. Desikachary and Maheshwari, 1958, p. 28, fig. 1; Fenner, 1982 , p. 124 , pl. 31 , figs. $1-2$.

Rossiella symmetrica Fenner, in press. Synonyms: Bogorovia veniamini Jousé sensu Gombos, 1976, p. 593, pl. 1, figs. 6-7, pl. 12, figs. 1, 2, 4; Rossiella sp. Gombos and Ciesielski, 1983, pl. 24, figs. 1-2. Fenner, in press, pl. 1, figs. 2-4; Fenner, 1982, p. 124, pl. 31, figs. 3-7 (as Rossiella sp. A Gombos (in prep.).

\section{Genus ROUXIA Brun and Héribaud, in Héribaud, 1893}

Rouxia hannae Jousé, 1973. Jousé, 1973, pp. 349-350, pl. 2, fig. 13. Rouxia obesa Schrader, in Schrader and Fenner, 1976. Schrader and Fenner, 1976, p. 997, pl. 24, figs. 5-6. 
Genus RUTILARIA Greville, 1863

Rutilaria sp. (Plate 2, Fig. 6.)

Remarks. Only the specimen illustrated on Plate 2 was found. More observations are necessary to decide whether its asymmetrical shape is an abnormality or of taxonomic value.

\section{Genus SCEPTRONEIS Ehrenberg, 1844,}

Sceptroneis pesplanus Fenner and Schrader, in Schrader and Fenner, 1976. Schrader and Fenner, 1976, p. 998, pl. 22, figs. 30-31, pl. 25 , figs. $10-11$.

Sceptroneis pupa Schrader and Fenner, 1976. Schrader and Fenner, 1976, p. 999, pl. 22, figs. 17-21, pl. 24, figs. 11-13.

Genus SKELETONEMA Greville, 1865

Skeletonema harbadense Greville, 1865. Greville, 1865c, p. 43, pl. 5, fig. 1.

Skeletonema utriculosum Brun, 1891. Brun, 1891, p. 44, pl. 11, fig. 1a-b.

\section{Genus STEPHANOPYXIS Ehrenberg, 1844}

Stephanopyxis aculeata (Ehrenberg) Grunow var. Fenner, 1982, p. 128, pl. 1, figs. 1-4.

Stephanopyxis grunowii Grove and Sturt, 1888, in A. Schmidt et al. 1874-. A. Schmidt et al., 1974-, pl. 130, figs. 1-6.

Stephanopyxis minuta Greville, 1865. Synonyms: Creswellia minuta Greville, 1865a, p. 4, pl. 1, fig. 13, not Stephanopyxis minuta (Grunow) A. Cleve, in Cleve-Euler, 1941, pl. 1, fig. 12f. Greville, 1865 a, p. 4, pl. 1, fig. 13.

Stephanopyxis superba (Greville) Grunow, 1884. Greville, 1861d, p. 68 , pl. 8, figs. 3-5.

Stephanopyxis turris (Greville and Arnott) Ralfs, in Pritchard, 1861. Hustedt, 1930, p. 304, fig. 140; Grunow, 1884, p. 87.

Stephanopyxis turris (Greville and Arnott) Ralfs, in Pritchard var. cylindrus Grunow, 1884. Grunow, 1884, p. 87, pl. 5(E), fig. 7-14.

\section{Genus STICTODISCUS Greville, 1861}

\section{Stictodiscus spp.}

Remarks. Single specimens belonging to this genus were found only very sporadically, and species-level determinations were not attempted. Species of this genus seem to be predominantly restricted to the littoral zone.

\section{Genus SYNEDRA Ehrenberg, 1830}

Synedra jouseana Sheshukova-Poretzkaya, 1962. Sheshukova-Poretzkaya, 1962, p. 208, fig. 4; Schrader, 1973, p. 710, pl. 23, figs. 21$23,25,38$.

Synedra aff. miocenica Schrader, 1976. Schrader, 1976, p. 94, pl. 1, fig. 1 .

Remarks. This species differs from the species described by Schrader (1976) in that it does not have the narrowed ends. In the shorter specimens the sides are not parallel, but the valve outline is narrowly elliptical.

\section{Genus THALASSIONEMA Grunow, in Van Heurck, 1881}

Thalassionema nitzschioides Grunow, in Van Heurck, 1881. Hustedt, 1959, pp. 244-246, fig. 725; Hasle and Mendiola, 1967, p. 111, figs. 5, 27-34, 39-44.

Thalassionema nitzschioides Grunow var. parva Heiden, in Heiden and Kolbe, 1928. Heiden and Kolbe, 1928, p. 564, fig. 118.

\section{Genus THALASSIOSIRA Cleve, 1873}

Thalassiosira bukryi Barron, 1983. Synonyms: Coscinodiscus sp. 1 Fenner, 1977, p. 517, pl. 6, figs. 7-8; Coscinodiscus sp. 5 Fenner, 1977 , p. 517, pl. 6, fig. 6. Barron, 1983, p. 511, pl. 4, figs. 1-2, pl. 6, fig. 9.

Thalassiosira eccentrica (group) (Ehrenberg) Cleve, 1904. Hustedt, 1930, p. 388, fig. 201. Simonsen, 1974, p. 9, pl. 2, figs. 1-3.

Thalassiosira fraga Schrader, in Schrader and Fenner, 1976. Schrader and Fenner, 1976, p. 1001, pl. 16, figs. 9-12.

Thalassiosira leptopus (Grunow) Hasle and Fryxell, 1977. Hasle and Fryxell, 1977, pp. 15-18, pl. 1-4.
Thalassiosira mediaconvexa Schrader, in Schrader and Fenner, 1976. Synonyms: Thalassiosira dubiosa Schrader, in Schrader and Fenner, 1976, p. 1001, pl. 35, fig. 6, not figs. 4-5. Thalassiosira? sp. 1 Fenner, 1977, p. 533, pl. 3, figs. 7-8. Schrader and Fenner, 1976, p. 1002 , pl. 36 , fig. 1 .

\section{Genus THALASSIOTHRIX Cleve and Grunow, 1880}

Thalassiothrix longissima Cleve and Grunow, 1880. Hasle and Mendiola, 1967, p. 114, fig. 20.

Remarks. As generally only fragments of $T$. longissima and Thalassionema nitzschioides (T. longissima being heteropolar, $T$. nitzschioides being isopolar) were found, distinction between them was impossible in most cases, and they are listed together.

\section{Genus TRICERATIUM Ehrenberg, 1839}

Triceratium americanum Ralfs, in Pritchard, 1861. A. Schmidt et al. 1874-, pl. 76, fig. 27 (pl. 76, fig. 28 is in error, see Boyer, 1900, p. 721 ).

Triceratium cinnamomeum Greville, 1863. Van Heurck, 1880, pl. 126, fig. 1; Kolbe, 1954, p. 47, pl. 2, fig. 18.

Triceratium inconspicuum Greville, 1861 var. inconspicuum. Greville, 1861 a, p. 45 , pl. 8 , fig. 10 .

Triceratium inconspicuum Greville var. trilobata Fenner, 1977. Synonym: Triceratium barbadense Greville sensu Kanaya, 1957, pp. 100-101, pl. 7, figs. 1-4. Fenner, 1982, p. 132, pl. 17, figs. 5-6; pl. 27 , figs. 5-6.

Triceratium aff. zonulatum Greville, 1865. Fenner, 1982, p. 132, pl. 17, fig. 9.

Triceratium kanayae Fenner, in press. Kanaya (1957), pp. 102-103, pl. 7, figs. 5-7 (as Triceratium sp. A); Fenner, in press, pl. 1, figs. 5-6.

Remarks. Three- and four-angled varieties were found to co-occur in samples from DSDP Site 220.

Triceratium kanayae var. quadriloba Fenner, in press. Fenner, in press, pl. 2.

Triceratium sp. 1. (Plate 2, Fig. 7.)

Remarks. This species, very similar to Lisitzinia ornata but differing in the lack of the deep folds between the central part and the angles, was found in the middle Eocene (P10) of DSDP Site 220.

\section{Genus TRINACRIA Heiberg, 1863}

Trinacria excavata Heiberg f. tetragona A. Schmidt, 1888, in A. Schmidt et al., 1874 - Illustration: A. Schmidt et al., 1874-, pl. 152, figs. 26-28; Fenner, 1977, pp. 535-536, pl. 27, figs. 9-11.

Trinacria praetenuis (Greville) Grunow, 1884. Synonym: Triceratium perminutum Greville, 1864 b, p. 89 , pl. 13, fig. 18. Greville, 1864 b, p. 89 , pl. 13, fig. 16; Fenner, 1982, p. 133, pl. 28, figs. 1-2.

Trinacria subcapitata (Greville) Grunow, 1884. Greville, 1863a, p. 244 , pl. 10 , fig. 20 ; Grunow, 1884 , p. 69 ; Fenner, 1982, p. 133 , pl. 28, figs. 3-8.

\section{Genus TROCHOSIRA Kitton, 1871}

Trochosira spinosa Kitton, 1871. Kitton, 1871, p. 170, pl. 14, figs. 6-7; A. Schmidt et al., 1874-, pl. 180, fig. 49; pl. 176, fig. 56.

\section{Genus XANTHIOPYXIS Ehrenberg, 1844}

Xanthiopyxis acrolopha Forti, 1912. Forti, 1912, p. 84; Forti, 1913, pp. 15-16, pl. 2, figs. $22,24,27-28,30-37$.

Xanthiopyxis oblonga Ehrenberg, 1844. Hanna, 1927, p. 124; Hanna, 1932, p. 226.

Xanthiopyxis ovalis Lohmann, 1938. Synonym: Liradiscus rugulosus Forti, 1913, p. 1559, pl. 12, fig. 23. Lohmann, 1938, p. 91, pl. 20 , fig. 2; pl., 22, fig. 12; Lohmann, 1974, p. 25, pl. 5, fig. 11.

\section{Genera Incertae Sedis}

Genus et Species indet. (1) Fenner, 1982. Illustration: Fenner, 1982, pl. 8, figs. 1-2.

Genus et species indet. (3)

Remarks. Only fragments of this species were found. The valves or skeletons are heavily silicified and consist of a central thickening extending laterally at each end into a narrow prolongation. Both the central part and the prolongations are coarsely areolated, the areolae being arranged in longitudinal rows with ribs between the rows. 
Stratigraphic occurrence: This species is found in the late Eocene of DSDP Sites 292 and 217.

\section{Genus MACRORA Hanna, 1932}

Macrora barbadiensis (Deflandre) Bukry, 1978. Loeblich et al., 1968, p. 207.

Macrora stella (Aspeitia) Hanna, 1932. Hanna, 1932, p. 196, pl. 12, fig. 7.

\section{Genus SPERMATOGONIA Leuduger-Fortmorel, 1892}

\section{Spermatogonia spp.}

Remarks. As only fragments of species belonging to this genus have been found, no species determination was attempted.

\section{ACKNOWLEDGMENTS}

This research was financially supported by DFG Grant Fu-119/6 and NSF Grant WHOI-26987. I am grateful to D. Fütterer, M. Sarnthein, and U. Pflaumann for their interest in this study. I thank L. H. Burckle and C. Sancetta for helpful comments and for reviewing the manuscript. Miss Schmidtmann helped type the manuscript.

\section{REFERENCES}

Agardh, C. A., 1824. Systema algarum: Lund (Literis Berlingianis). 1832. Conspectus Criticus Diatomacearum (Pt. 4): Lund (Literis Berlingianis), 48-66.

Andrews, G. W., 1975. Taxonomy and stratigraphic occurrence of the marine diatom Genus Rhaphoneis. 3rd Symp. Rec. Fossil Mar. Diatoms, Kiel. Beih. Nova Hedwigia, 53:193-229.

Barker, P. F., Carlson, R. L., Johnson, D. A., and Shipboard Scientific Party, 1981. Leg 72: Southwest Atlantic circulation and Rio Grande Rise tectonics. Geol. Soc. Am. Bull., 92:294-309.

Barron, J. A., 1983. Latest Oligocene through early middle Miocene diatom biostratigraphy of the eastern tropical Pacific. Mar. Micropaleontol., 7:487-515.

Beckmann, J. P., 1971. The foraminifera of Sites 68 to 75. In Tracey, J. I., Jr., Sutton, G. H., et al., Init. Repts. DSDP, 8: Washington (U.S. Govt. Printing Office), 713-726.

Berggren, W. A., Lohman, G. P., and Poore, R. Z., 1974. Shore laboratory report on Cenozoic planktonic foraminifera: Leg 22. In von der Borch, C. C., Sclater, J. G., et al., Init. Repts. DSDP, 22: Washington (U.S. Govt. Printing Office), 635-656.

Boersma, A., 1977. Cenozoic planktonic foraminifera-DSDP Leg 39 (South Atlantic). In Supko, P. R., Perch-Nielsen, K., et al., Init. Repts. DSDP, 39: Washington (U.S. Govt. Printing Office), $567-590$.

Bory de Saint-Vincent, J. B. M., 1831. Contributions to Dictionnaire classique d'Histoire naturelle (Vol. 17): Paris.

Boström, K., Kraemer, T., and Gartner, S., 1973. Provenance and accumulation rates of opaline silica, $\mathrm{Al}, \mathrm{Ti}, \mathrm{Fe}, \mathrm{Mn}, \mathrm{Cu}, \mathrm{Ni}$ and $\mathrm{Co}$ in Pacific pelagic sediments. Chem. Geol., 11:123-148.

Boyer, C. S., 1900. Biddulphoid forms of North American Diaomaceae. Proc. Acad. Nat. Sci. Philadelphia, Pt. 3:685-748.

Brun, J., 1891. Diatomées. Mém. Soc. Phys. Hist. nat. Genève, 31: 1892. Notes sur quelques espèces nouvelles. In Tempère, J. (Ed.), Le Diatomiste (Vol. 1): Paris (M. J. Tempère), 173-177, pl. 14.

1896. Diatomées Miocènes. In Tempère, J. (Ed.), Le Diatomiste (Vol. 2) Paris (M. J. Tempère), 229-247, pl. 19-24.

Bukry, D., 1971a. Coccolith stratigraphy Leg 7, Deep Sea Drilling Project. In Winterer, E. L., Riedel, W. R., et al., Init. Repts. DSDP, 7, Pt. 2: Washington (U.S. Govt. Printing Office), 1513-1528.

1971b. Coccolith stratigraphy, Leg 8, Deep Sea Drilling Project. In Tracey, J. I., Jr., Sutton, G. H., et al., Init. Repts. DSDP, 8: Washington (U.S. Govt. Printing Office), 791-808. 1974. Coccolith and silicoflagellate stratigraphy, eastern Indian Ocean, Deep Sea Drilling Project, Leg 22. In von der Borch, C. C., Sclater, J. G., et al., Init. Repts. DSDP, 22: Washington (U.S. Govt. Printing Office), 601-608.

, 1977. Coccolith and silicoflagellate stratigraphy, South Atlantic Ocean, Deep Sea Drilling Project Leg 39. In Supko, P. R., Perch-Nielsen, K., et al., Init. Repts. DSDP, 39: Washington (U.S. Govt. Printing Office), 825-840.
1978. Cenozoic silicoflagellate and coccolith stratigraphy, northwestern Atlantic Ocean, Deep Sea Drilling Project Leg 43. In Benson, W. E., Sheridan, R. E., et al., Init. Repts. DSDP, 44: Washington (U.S. Govt. Printing Office), 775-805.

Burckle, L. H., 1972. Late Cenozoic planktonic diatom zones from the eastern Equatorial Pacific. 1st Symp. Rec. Fossil Mar. Diatoms, Bremerhaven. Beih. Nova Hedwigia, 39:217-250.

Burckle, L. H, and Trainer, J., 1979. Middle and late Pliocene diatom datum levels from the central Pacific. Micropaleontology, 25: 281-293.

Castracane, A. F., 1886. Report on the Scientific Results of the Voyage of H.M.S. Challenger during the Years 1873-76: Botany (Vol. 2): London (HMSO).

Cleve, P. T., 1873. Examination of diatoms found on the surface of the sea of Java. Bihang Svenska Vetanskaps Akad. Handl. 1:1-13, Stockholm.

1904. Plankton table for the North Sea. Cons. Expl. Mer. Bull., 1903-1904.

Cleve, P. T., and Grunow, A.; 1879 [1880]. Beiträge zur Kenntnis der arktischen Diatomeen. K. Svenska Vetenskapsakad. Handl., 17: 1215, (Referat, Botan. Centralblatt, 5:65-69, 1881).

Cleve-Euler, A., 1941. Altteriaere Diatomeen und Silicoflagellaten im Inneren Schwedens. Palaeontographica, 92:165-209.

1951. Die Diatomeen von Schweden und Finnland. K. Svenska Vetenskaps Akad. Handl. Fjärde Serien, 2 (Pt. I, Centricae: Stockholm (Almquist and Wiksells Boktryckeri).

McCollum, D. W., 1975. Diatom stratigraphy of the Southern Ocean. In Hayes, D. E., Frakes, L. A., et al., Init. Repts. DSDP, 28: Washington (U.S. Govt. Printing Office), 515-572.

Desikachary, T. V., and Maheshwari, C. L., 1958. Fossil diatoms from Colebrook Island. J. Ind. Bot. Soc., 38(no. 1):27-41.

Dinkelman, M. G., 1973. Radiolarian stratigraphy: Leg 16, Deep Sea Drilling Project. In van Andel, T. H., Heath, G. R., et al., Init. Repts. DSDP, 16: Washington (U.S. Govt. Printing Office), 747-814.

Douglas, R. G., 1973. Planktonic foraminiferal biostratigraphy in the central North Pacific Ocean. In Winterer, E. L., Ewing, J. I., et al., Init. Repts. DSDP, 17: Washington (U.S. Govt. Printing Office), 673-694.

Douglas, R. G., and Savin, S. M., 1975. Oxygen and carbon isotope analyses of the Tertiary from Shatsky Rise and other sites in the North Pacific Ocean. In Larson, R. L., Moberly, R., et al., Init. Repts. DSDP, 32: Washington (U.S. Govt. Printing Office), 509-520.

Dzinoridze, R. N., Jousé, A. P., Koroleva-Golikova, G. S., Kozlova, G. E., Nagaeva, G. S., Petrushevskaya, M. G., and Strelnikova, N. I., 1976. Diatom and radiolarian cenozoic stratigraphy, Norwegian Basin. DSDP Leg 38. In Talwani, M., Udintsev, G., et al., Init. Repts. DSDP, Suppl. to Vols. 38, 39, 40, and 41: Washington (U.S. Govt. Printing Office), 289-427.

Dzinoridze, R. N., Jousé, A. P., and Strelnikova, N. I., 1979. Description of the diatoms. The History of the Microplankton of the Norwegian Sea (on the Deep Sea Drilling Materials). Acad. Sci. U.S.S.R., Zool. Inst., Explorations of the Faunas of the Seas, 23(31): 32-71.

Ehrenberg, C. G., 1830. Beiträge zur Kenntnis der Organisation der Infusorien und ihrer geographischen Verbreitung besonders in $\mathrm{Si}$ birien. Abh. K. Akad. Wiss. Berlin, pp. 1-88.

1837. Die fossilen Infusorien und die lebendige Dammerde. Abh. K. Akad. Wiss. Berlin.

1838. Über die Bildung der Kreidefelsen und des Kreidemergels durch unsichtbare Organismen. Abh. K. Akad. Wiss. Berlin, pp. 59-147.

1839. Über noch jetzt zahlreich lebende Thierarten der Kreidebildung und den Organismus der Polythalamien. Anh. K. Akad. Wiss. Berlin, pp. 81-174.

1840. Über ausgezeichnete jetzt noch lebende peruanische und mexikanische Meeres-Infusorien, welche mit zur Erläuterung rätselhafter fossiler Formen der Kreidebildung dienen. Ber. $K$. Preuss. Akad. Wiss. Berlin, pp. 157-162.

1841. Verbreitung und Einfluss des mikroskopischen Lebens in Süd- und Nordamerika. Abh. K. Akad. Wiss. Berlin, Pt. 1, 291-445. 
1843. Mitteilungen über zwei neue asiatische Lager fossiler Infusorien-Erden aus dem russischen Trans-Kaukasien (Grusien) und Sibirien. Ber. K. Preuss. Akad. Wiss. Berlin, pp. 43-49. 1844. Mitteilung über zwei neue Lager von Gebirgsmassen aus Infusorien als Meeres-Absatz in Nordamerika und eine Vergleichung derselben mit den organischen Kreidegebilden in Europa und Afrika. Ber. K. Preuss. Akad. Wiss. Berlin, pp. 57-97. (Notice by J. W. Bailey, 1845. "Ehrenberg's observations on the fossil infusoria of Virginia and Maryland, and comparisons of the same with those found in the chalk formations of Europe and America". Am. J. Sci., 48:201-204).

, 1845. Neue Untersuchungen über das kleinste Leben als geologisches Moment....mit kurzer Charakteristik von 10 neuen Genera und 66 neuen Arten. Ber. K. Preuss. Akad. Wiss. Berlin. pp. 53-88.

1854. Mikrogeologie. Das Erden und Felsen schaffende Wirken des unsichtbar kleinen selbständigen Lebens auf der Erde: Leipzig. (Leopold Voss).

Ellis, C. H., 1975. Calcareous nannofossil biostratigraphy-DSDP Leg 31. In Karig, D. E., Ingle, J. C., Jr., et al. Init. Repts. DSDP, 31: Washington (U.S. Govt. Printing Office), 655-676.

Fenner, J., 1977. Cenozoic diatom biostratigraphy of the equatorial and southern Atlantic ocean. In Supko, P. R., Perch-Nielsen, K., et al., Init. Repts. DSDP, Suppl. to Vols. 38, 39, 40, and 41: Washington (U.S. Govt. Printing Office), 491-623.

1982. Diatoms in the Eocene and Oligocene sediments off NW Africa, their stratigraphic and paleogeographic occurrence [Ph.D. dissert.] University of Kiel.

in press. Eocene-Oligocene planktic diatom stratigraphy in the low latitudes and the high southern latitudes. Micropaleontology.

Forti, A., 1909. Studi per una Monografia del genere Pyxilla (Diatomee) e dei generi affini. Nuova Notarisia, Ser. 20:5-24.

1912. Primo elenco delle Diatomee fossili contenute nei calcari marmori biancastri di Monte Gibbio (Sassuolo-Emilia). Nuova Notarisia, Ser. 23:79-87.

1913. Contribuzioni diatomologiche. XIII. Diagnoses Diatomacearum quarumdam fossilium italicarum. Atti R. Inst. Veneto Sci. Lett. Arti, 72:1567-1700.

Fodor, R. V., and Thiede, J., 1977. Volcanic breccia from DSDP Site 357: implications for the composition and origin of the Rio Grande Rise. In Supko, P. R., Perch-Nielsen, K., et al., Init. Repts. DSDP, 39: Washington (U.S. Govt. Printing Office), 537-544.

Frenguelli, J., 1949. Diatomeas fósiles de los Yacimientos Chileanos de Tiltil y Mejillones. Darwiniana, 9(no. 1):97-157.

Gartner, S. Jr., 1971. Calcareous nannofossil age determinations: Leg 7, Deep Sea Drilling Project. In Winterer, E. L., Riedel, W. R., et al., Init. Repts. DSDP, 7, Pt. 2: Washington (U.S. Govt. Printing Office), 1509-1512.

1974. Nannofossil biostratigraphy, Leg 22, Deep Sea Drilling Project. In von der Borch, C. C., Sclater, J. G., et al., Init. Repts. DSDP, 22: Washington (U.S. Govt. Printing Office), 577-600.

Gleser, S. I., and Jousé, A. P., 1974. Diatoms and silicoflagellates in the Eocene of the equatorial Atlantic. In: Jousé, A. P. (Ed.), Micropaleontology of Oceans and Seas: Moscow: Acad. Nauk S.S.S.R) pp. 49-62.

Göke, G., 1958. Einführung in die Präparation der fossilen Diatomeen. Pts. 1. und 2. Der Aufschluss, 9.

Gombos, A. M., 1977. Paleogene and Neogene diatoms from the Falkland Plateau and Malvinas Outer Basin, Leg 36, Deep Sea Drilling Project. In Barker, P. F., Dalziel, I. W. D., et al., Init. Repts. $D S D P$, 36: Washington (U.S. Govt. Printing Office), 575-687.

1980. The early history of the diatom family Asterolampraceae. Bacillaria, 3:227-272.

1983. Middle Eocene diatoms from the South Atlantic. In Ludwig, W. J., Krasheninnikov, V. A., et al., Init. Repts. DSDP, 71: Washington (U.S. Govt. Printing Office).

Gombos, A. M., and Ciesielski, P. F., 1983. Late Eocene to early Miocene diatoms from the southwest Atlantic. In Ludwig, W. J., Krasheninnikov, V. A., et al., Init. Repts. DSDP, 71; Washington (U.S. Govt. Printing Office).
Gray, S. F., 1821. A Natural Arrangement of British plants... with an Introduction to Botany (Vols. 1 and 2): (Diatomaceae) London (Baldwin, Craddock and Joy), 293-295.

Greville, R. K., 1860. A monograph of the genus Asterolampra, including Asteromphalus and Spatangidium. Trans. Microsc. Soc. London, N. S. 8:102-124.

1861a. Descriptions of new and rare diatoms. Series I. Trans. Microsc. Soc. London, NS 9:39-47.

$1861 \mathrm{~b}$. Descriptions of new and rare diatoms. Series II. Trans. Microsc. Soc. London, NS 9:67-73.

1861c. Descriptions of new and rare Diatoms. Series III. Trans. Microsc. Soc. London, NS 9:73-77.

1861d. Descriptions of new and rare diatoms. Series IV.

Trans. Microsc. Soc. London, NS 9:78-87.

1862a. Descriptions of new and rare diatoms. Series V.

Trans. Microsc. Soc. London, NS 10:18-29.

1862b. Descriptions of new and rare diatoms. Series VI,

Trans. Microsc. Soc. London, NS 10:89-96.

1862c. Descriptions of new and rare diatoms. Series VII.

Q. J. Microsc. Sci., NS 2:231-237.

1862d. On the Asterolamprae of the Barbados deposit. $Q$. J. Microsc. Sci., NS 2:41-58.

1863a Descriptions of new and rare diatoms. Series VIII. Q. J. Microsc. Sci., NS 3:13-22.

$1863 \mathrm{~b}$. Descriptions of new and rare diatoms. Series IX. Trans. Microsc. Soc. London, NS 11 p. 63-79.

1863c. Descriptions of new and rare diatoms. Series X. $Q$.

J. Microsc. Sci., NS 3:227-240.

1865a. Descriptions of new and rare diatoms. Series XIV.

Trans. Microsc. Soc. London, NS 13:1-37.

$1865 \mathrm{~b}$. Descriptions of new and rare diatoms. Series XV.

Trans. Microsc. Soc. London, NS 13:24-37.

$1865 \mathrm{c}$. Descriptions of new and rare diatoms. Series XVI.

Trans. Microsc. Soc. London, NS 13:43-60.

$1865 \mathrm{~d}$. Descriptions of new and rare diatoms. Series XVII.

Trans. Microsc. Soc. London, NS 13:97-108.

1866a. Descriptions of new and rare diatoms. Series XVIII.

Trans. Microsc. Soc. London, NS 14:1-12.

$1866 \mathrm{~b}$. Descriptions of new and rare diatoms. Series XIX,

Trans. Microsc. Soc. London, NS 14:77-88.

1866c. Descriptions of new and rare diatoms. Series XX. Trans. Microsc. Soc. London, NS 14:121-130.

Grove, E. and Sturt, G., 1886-1889. On a fossil marine diatomaceous deposit from Oamaru, Otago, New Zealand. J. Quekett Microsc. Club, Ser. 2. Part I, 2:321-332. Part II, 3:7-12. Part III, 3:63-78. Appendix, 3:131-148.

Grunow, A., 1862. Die osterreichischen Diatomaceen nebst Anschluss einiger neuer Arten von anderen Lokalitäten und einer kritischen Übersicht der bisher bekannten Gattungen und Arten. Verh. Kaiserl-K. Zool. Bot. Ges. Wien, 12:315-472, 545-585.

1884. Diatomeen von Franz Josef-Land. Denkschr. Kaiserl. Akad. Wiss., 48:53-112.

Hajós, M., 1976. Upper Eocene and lower Oligocene Diatomaceae, Archaeomonadaceae, and Silicoflagellatae in southwestern Pacific sediments, DSDP Leg 29. In Hollister, C. D., Craddock, C., et al., Init. Repts. DSDP, 35: Washington (U.S. Govt. Printing Of fice), 817-884.

Hammond, S. R., Kroenke, L. W., and Theyer, F., 1975. Northward motion of the Ontong-Java Plateau between -110 and -30 m.y. a paleomagnetic investigation of DSDP Site 289. In Andrews, J. E., Packham, G., et al., Init. Repts. DSDP, 30: Washington (U.S. Govt. Printing Office), 415-418.

Hanna, G. D., 1927. The lowest known Tertiary diatoms in California. J. Paleontol., I:103-126.

1930. A new genus of silicoflagellata from the Miocene of Lower California. J. Paleontol., 4:415-416.

1932. The diatoms of Sharktooth Hill, Kern County, California. Proc. Calif. Acad. Sci., Ser. IV, 20(no. 6):161-263.

Hanna, G. D., and Brigger, A. L., 1970. Observations on Liostephania. Beih. Nova Hedwigia, 31:89-101.

Hanna, G. D., and Grant, W. M., 1926. Expedition to the Revilla Gigedo Islands, Mexico, in 1925. II. Miocene marine diatoms from 
Maria Madre Island, Mexico. Proc. Calif. Acad. Sci., Ser. 4, 15: 115-193.

Haq, B., and Lipps, J. H., 1971. Calcareous nannofossils. In: Tracey, J. I., Jr., Sutton, G. H., et al., Init. Repts. DSDP, 8: Washington (U.S. Govt. Printing Office), 777-790.

Hasle, G. R., and Fryxell, G. A., 1977. The genus Thalassiosira: Some species with a linear areola array. In Simonsen, R. (Ed.), Fourth Symp. Rec. Fossil Mar. Diatoms, Oslo: Proceedings. Beih. Nova Hedwigia, 54:15-66.

Hasle, G. R., and de Mendiola, B. R. E., 1967. The fine structure for some Thalassionema and Thalassiothrix species. Phycologia, 6:107-125.

Hassall, A. H., 1845. A History of the British Freshwater Algae (Including Descriptions of the Diatomaceae and Desmidiaceae): London (Taylor, Walton, and Maberly).

Hay, W. W., 1971. Preliminary dating by fossil calcareous nannoplankton, Deep Sea Drilling Project, Leg 8. In Tracey, J. I., Jr., Sutton, G. H., et al., Init. Repts. DSDP, 8: Washington (U.S. Govt. Printing Office), 809-818.

Heath, G. R., and Moberly, R., Jr., 1971a. Cherts from the western Pacific, Leg 7, Deep Sea Drililng Project. In Winterer, E. L., Riedel, W. R., et al., Init. Repts. DSDP, 7, Pt. 2: Washington (U.S. Govt. Printing Office), 991-1008.

1971b. Deep-sea turbidites from the western Pacific: Leg 7, Deep Sea Drilling Project. In Winterer, E. L., Riedel, W. R., et al., Init. Repts. DSDP, 7, Pt. 2: Washington (U.S. Govt. Printing Office), 1009-1010.

Heiberg, P. A. C., 1863. Conspectus criticus Diatomacearum Danicarum: Copenhagen (Wilh. Priors F $\phi$ rlag).

Heiden, H., and Kolbe, R. W. M., 1928. Die marinen Diatomeen der Deutschen Südpolar-Expedition 1901-1903, 8(Bot. Heft 5): 447-745.

Hendey, N. I., 1969. Pyrgupyxis, a new genus of diatoms from a south Atlantic Eocene core. Occas. Pap. Calif. Acad. Sci., 72:1-5.

Héribaud, J., 1893. Les Diatomées d'Auvergne: Paris (Librairie des Sci. Naturelles).

Hustedt, F., 1930. Die Kieselalgen Deutschlands, Österreichs und der Schweiz mit Berücksichtigung der übrigen Länder Europas sowie der angrenzenden Meeresgebiete. In Rabenhorst, L. (Ed.), Kryptogamenflora von Deutschland, Osterreich und der Schweiz (Vol. 7, Pt. 1): Leipzig (Akademische Gesellschaft).

1958. Diatomeen aus der Antarktik und dem Südatlantik. Deutsche Antarkt. Exped. 1938-1939, 2:103-191.

1959. Die Kieselalgen Deutschlands, Österreichs und der Schweiz. Pt. 2, Bremen. In Rabenhorst, L. (Ed.), Kryptogamenflora von Deutschland, Österreich und der Schweiz (Vol. 7, Pt. 2): Leipzig (Akademische Gesellschaft), 737-845.

Ingle, J. C., Karig, D. E., et al., 1975. Site 292. In Karig, D. E., Ingle, J. C., Jr., et al., Init. Repts. DSDP, 31: Washington (U.S. Govt. Printing Office), 67-130.

Johnson, D. A., in press. Paleocirculation of the southwestern Atlantic. In Barker, P. F., Carlson, R. L., Johnson, D. A., et al., Init. Repts. DSDP, 72: Washington (U.S. Govt. Printing Office).

Jousé, A. P., 1973. Diatoms in the Oligocene-Miocene Biostratigraphic Zones of the Tropical Areas of the Pacific Ocean. 2nd Symp. Rec. Fossil Mar. Diatoms, London. Beih. Nova Hedwigia, 45:333-364. 1978. Novii iskopaemii rod diatomei Lisitzinia (Bacillariophyta). Morsk. mikropaleontol. Akad. Nauk, SSSR, Moscow, pp. 47-48, plate 10. (In Russian)

(Ed.), 1977. Atlas of Microorganisms in Bottom Sediments of the Oceans (Diatoms, Radiolaria, Silicoflagellates, and Coccoliths): Moscow (Nauka).

Jousé, A. P., and Sheshukova-Poretzkaya, V. S., 1971. Genus novum Riedelia Jousé et Sheshukova-Poretzkaya (Bacillariophyta). Nov. System. Plant, non Vascular., 8:19-25.

Kanaya, T., 1957. Eocene diatom assemblages from the "Kellogg" and "Sidney" shales, Mt. Diablo Area, California. Sci. Rep. Tohoku Univ., Ser. 2 (Geol.), 28:1-124.

1959. Miocene diatom assemblages from the Onnagawa Formation and their distribution in the correlative formations in Northeast Japan. Sci. Rep. Tohoku Univ., Ser. 2 (Geol.), 30: 1-130.

1971. Some aspects of pre-Quaternary diatoms in the oceans. In Funnell, B. M., and Riedel, W. R. (Eds.), The Micropaleontology of the Oceans: Proceedings of the Symposium held in
Cambridge, Sept. 1967, "Micropaleontology of Marine Bottom Sediments," pp. 545-562.

Karsten, G., 1928. Abteilung Bacillariophyta (Diatomeae). In Engler, A., and Prantl., K. (Eds.) Die natürlichen Pflanzenfamilien (2nd ed.),: Leipzig (Verlag W. Engelmann), 2:105-345.

Keigwin, L. D., Jr., 1980. Paleoceanographic change in the Pacific at the Eocene-Oligocene boundary. Nature, 287:722-725.

Kitton, F., 1871. Diatomaceous deposits from Juetland, Part 2. J. Quekett Microsc. Club, 2:168-171.

Kolbe, R. W., 1954. Diatoms from equatorial Pacific cores. Rept. Swedish Deep Sea Exped., 6:1-49.

Kützing, F. F., 1844. Die kieselschaligen Bacillarien oder Diatomeen. (Nordhausen, 1865).

Leinen, M., 1981. Biogenic silica accumulation in the central equatorial Pacific and its implications for Cenozoic paleoceanography. Geol. Soc. Am. Bull., Pt. II, 90(no. 9):1310-1376.

Leuduger-Fortmorel, G., 1892. Diatomées de la Malaisie. Ann. Jardin Bot. Buitenzorg, 11:1-60.

Lohmann, K. E., 1938. Pliocene diatoms from the Kettleman Hills, California. U.S. Geol. Surv., Prof. Pap., 189-C:81-102.

1974. Lower middle Miocene marine diatoms from Trinidad. Verh. Nat. Ges. Basel, pp. 1-47

McElhinny, M. W., 1970. Formation of the Indian Ocean. Nature, 228:977.

McKenzie, D. P., and Sclater, J. G., 1971. The evolution of the Indian Ocean since the Late Cretaceous. Geophys. J. R. Astronom. Soc., 25:437-528.

Mann, A., 1907. Report on the diatoms of the Albatross voyages in the Pacific Ocean, 1888-1904. Contr. U.S. Nat. Herbarium, 10(Pt. 5):221-419.

Martini, E., and Worsley, T., 1971. Tertiary calcareous nannoplankton from the western equatorial Pacific. In Winterer, E. L., Riedel, W. R., et al., Init. Repts. DSDP, 7, Pt. 2: Washington (U.S. Govt. Printing Office), 1471-1508.

Maxwell, A. E., von Herzen, R. P., et al., 1970. Site 22. In Maxwell, A. E., von Herzen, R. P., et al., Init. Repts. DSDP, 3: Washington (U.S. Govt. Printing Office), 413-440.

Mills, F. W., 1933-1935. An Index to the Genera and Species of the Diatomaceae and Their Synonyms, 1816-1932: London (Wheldon and Wesley).

Moore, T. C., 1971. Radiolaria. In Tracey, J. I., Jr., Sutton, G. H., et al., Init. Repts. DSDP, 8: Washington (U.S. Govt. Printing Office), 727-776.

Pantocsek, J., 1889. Beiträge zur Kenntnis der fossilen Bacillarien Ungarns (Vol. 2). Brackwasser Bacillarien und Anhang: Analyse der marinen Depots von Borny, Bremia Vagy-Kürtös in Ungarn, Ananino und Kusnetzk in Russland.

1892. Beiträge zur Kenntnis der fossilen Bacillarien Ungarns (Vol. 3) Süsswasser Bacillarien. Anhang: Analysen 15 neuer Depots von Bulgarien, Japan, Mahren, Russland und Ungarn: Vagy-Tapolcsany (Julius Platzko).

Perch-Nielsen, K., 1977. Albian to Pleistocene calcareous nannofossils from the western South Atlantic, DSDP Leg 39. In Supko, P. R., Perch-Nielsen, K., et al., Init. Repts. DSDP, 39: Washington (U.S. Govt. Printing Office), 699-824.

Perch-Nielsen, K., Supko, P. R., et al., 1977. Site 357: Rio Grande Rise. In Supko, P. R., Perch-Nielsen, K., et al., Init. Repts. DSDP, 39: Washington (U.S. Govt. Printing Office), 231-328.

Pritchard, A., 1842-1852. A History of Infusoria, Living and Fossil: London (Whitaker).

1861. History of Infusoria, Including the Desmidiaceae and Diatomaceae, British and Foreign (4th ed.): London

Proshkina-Lavrenko, A. I., 1949-1951. Diatomovyi analis (3 vols.). Moscow.

Rattray, J., 1889. A revision of the genus Coscinodiscus and some allied genera. Proc. R. Soc. Edinburgh, 16:449-692.

1890. A revision of the genus Actinocyclus Ehrenberg. J. Quekett Microsc. Club, Ser. 2, 4:137-212.

Riedel, W. R., and Sanfilippo, A., 1971. Cenozoic radiolaria from the western tropical Pacific, Leg 7. In Winterer, E. L., Riedel, W. R., et al., Init. Repts. DSDP, 7, Pt. 2: Washington (U.S. Govt. Printing Office), $1529-1672$.

Roper, F. C. S., 1859. On the genus Biddulphia and its affinities. Trans. Microsc. Soc. London, 7:1-24. 
Roth, P. H, 1973. Calcareous nannofossils-Leg 17, Deep Sea Drilling Project. In Winterer, E. L., Ewing, J. I., et al., Init. Repts. DSDP, 17: Washington (U.S. Govt. Printing Office), 695-795.

Schmidt, A., 1874-. Atlas der Diatomeenkunde. Begun by A. Schmidt, continued by Schmidt, M., Fricke, F., Heiden, H., Mueller, O., and Hustedt, F.: Leipzig, Berlin (O. R. Reisland).

Schrader, H. J., 1973. Cenozoic diatoms from the northeast Pacific, Leg 18. In Kulm, L. D., von Huene, R., et al., Init. Repts. DSDP, 18: Washington (U.S. Govt. Printing Office), 673-797.

1974. Cenozoic marine planktonic diatom stratigraphy of the tropical Indian Ocean. In Fisher, R. L., Bunce, E. T., et al., Init. Repts. DSDP, 24: Washington (U.S. Govt. Printing Office), 887-967.

1976. Cenozoic marine planktonic diatom biostratigraphy of the Southern Pacific Ocean. In Hollister, C. D., Craddock, C., et al., Init. Repts. DSDP, 35: Washington (U.S. Govt. Printing Office), 605-672.

Schrader, H. J., and Fenner, J., 1976. Norwegian Sea cenozoic diatom biostratigraphy and taxonomy. In Talwani, M., Udintsev, G., et al., Init. Repts. DSDP, 38: Washington (U.S. Govt. Printing Office), 921-1099.

Shafik, S., 1975. Nannofossil biostratigraphy of the Southwest Pacific, Deep Sea Drilling Project, Leg 30. In Andrews, J. E., Packham, G., et al., Init. Repts. DSDP, 30: Washington (U.S. Govt. Printing Office), 549-598.

Sheshukova-Poretzkaya, V. S., 1962. Novie i redkie Bacillariophyta iz diatomovoi suiti Sakhalina. Uch. Zap. $1 \mathrm{gu}$, ser. Biol. Nauk (Leningrad Univ.), 49 (no. 313):203-211.

1967. Neogenovye Morskie Diatomovye Vodorsli Sakhali na i Kamchatki, 8:1-432.

Sheshukova-Poretzkaya, V. S., and Gleser, S. I., 1962. Bacillariophyta, Silicoflagellata and Ebriideae from Maikop series deposits (River Shibik, Krasnodar Region). (Diatomovie vodorosli, silikoflagellatii ebriidei iz maikopsikh otloznenii s. v. Shibik (Krasnodarski Krai). Uch. Zap., Ser. Biol. Nauk (Leningrad Univ.), 49: 171-202.

1964. Diatomaeae marinae novae e Palegeno Ucraineae. Acad. NAUK S.S.S.R., Nov. sist. nizschich rast. otdel bentii ottisk, isdatelbstwo Nauka, pp. 78-92.
Simonsen, R., 1974. The diatom plankton of the Indian Ocean Expedition of R.V. Meteor, 1964-1965. Meteor Forsch. Ergebn., Reihe $D, 19: 1-65$. 1979. The diatom system. Bacillaria, 2:9-71.

Simonsen, R., and Kanaya, T., 1961. Notes on the marine species of the diatom genus Denticula Kütz. Int. Rev. Ges. Hydrobiol., 46: 498-513.

Strelnikova, N. I., 1974. Diatomei Pozdnego Mela [Late Cretaceous diatoms of western Siberia]. Acad. Nauk, S.S.S.R., Roy 8.

Tempère, J., and Peragallo, H., 1907-1915. Diatomees du Monde Entier (2nd ed.) (Privately published.)

Thwaites, G. H. K., 1848. Further observations on the diatomaceae with descriptions of new genera and species. Ann. Mag. Nat. Hist., 1(ser. 2):161-172.

Tjalsma, E., in press. Eocene to Miocene benthic foraminifers from DSDP Site 516, Rio Grande Rise, South Atlantic. In Barker, P. F., Carlsen, R. L., Johnson, D. A., et al., Init. Repts. DSDP, 72: Washington (U.S. Govt. Printing Office).

Truan y Luard, A., and Witt, O. N., 1888. Diatomaceen der Polycystinen Kreide von Jeremie in Haiti, Westindia. J. Micrograph. Ann. (Berlin) 12.

Van Heurck, H., 1880-1885. Synopsis des diatomées de Belgique. Atlas, pl. 1-30 (1880); pl. 31-77 (1881); pl. 78-103 (1882); pl. 104-132 (1883); pl. A, B.C (1885).:Anvers (Ducaju et Cie.) 1896. A Treatise on the Diatomaceae: London

Van Landingham, S. L., 1967-1979. Catalogue of the Fossil and Recent Genera and Species of Diatoms and Their Synonyms.: Lehre (Cramer).

Vergnaud Grazzini, C., and Rabussier-Lointier, D., 1980. Compositions isotopiques de l'oxygène et du carbone des foraminifères tertiaires en Atlantique équatorial (site 366 du DSDP). Rev. Geol. Dynam. Geogr. Phys., 22:63-74.

Wallich, G. C., 1860. On the siliceous organisms found in the digestive cavities of the Salpae and their relation to the flint nodules of the Chalk Formation. Trans. Microsc. Soc. London, NS 8:36-55.

Weaver, F. M., and Gombos, A. M., Jr., 1981. Southern high-latitude diatom biostratigraphy. In Warme, T. C., Douglas, R. C., and Winterer, E. L. (Eds.), The Deep Sea Drilling Project: A Decade of Progress. Spec. Publ., 32:445-470. 

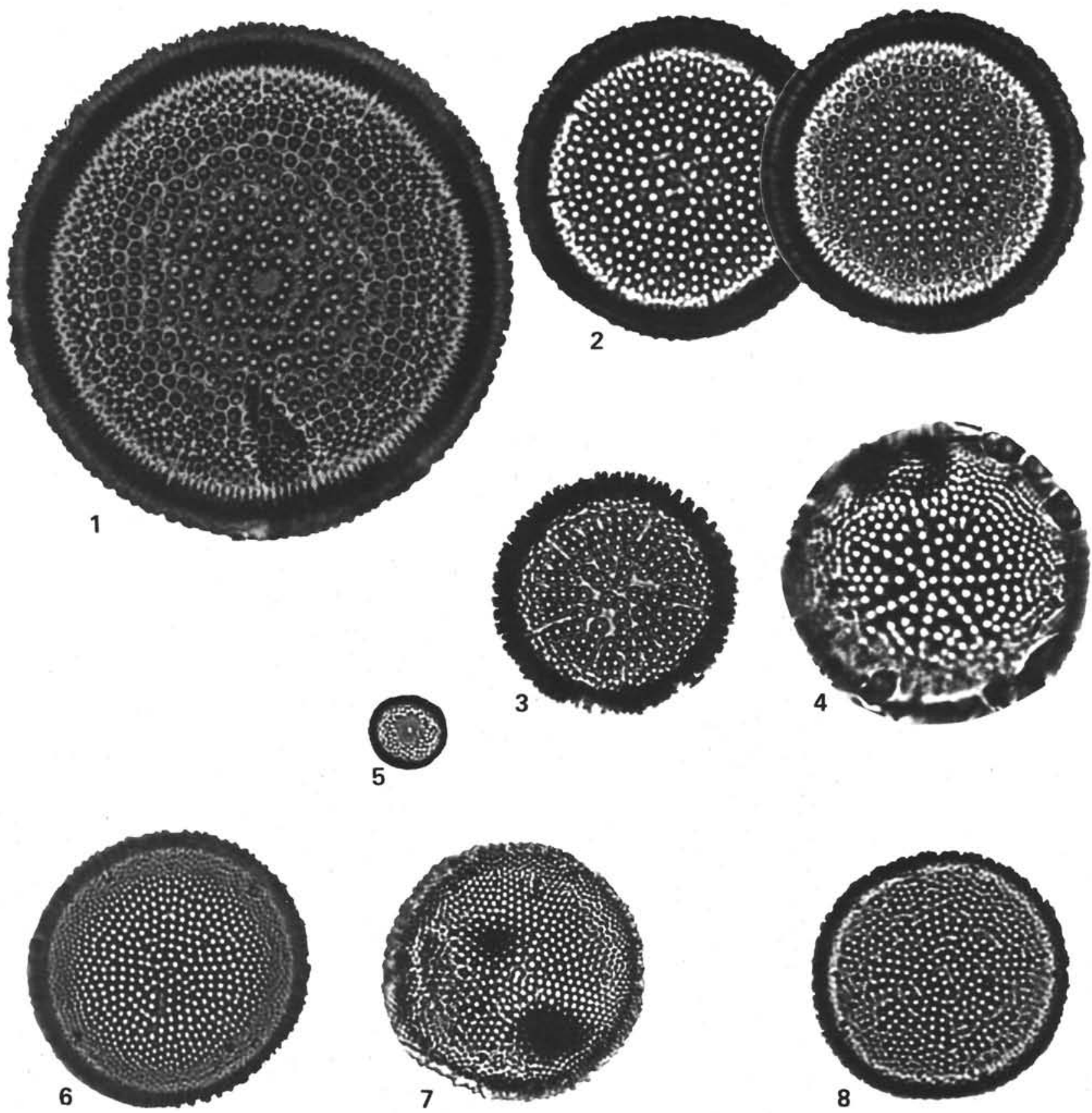

Plate 1. (All figures magnified $1500 \times$ ). 1-2. Cestodiscus pulchellus Greville (paratype), Nankoori, Nicobar Islands, Coll. DEBY, B.M. slide 9896. 3. Cestodiscus parmula Castracane, DSDP Sample 357-17-6, 96-97 cm. 4. Cestodiscus aff. trochus Castracane, DSDP Sample 357-15-2, 29-30 cm. 5. Trochosira? sp., DSDP Sample 357-24-5, 84-85 cm. 6-8. Cestodiscus stokesianus Greville, (6) Paratype, Moron deposit, Coll. Greville (slide obtained from Ref. Stokes), B.M. slide 3235, (7) DSDP Sample 289-97-4, 122-126 cm, (8) Moron deposit, Coll. Tulk, B.M. slide 53516. 

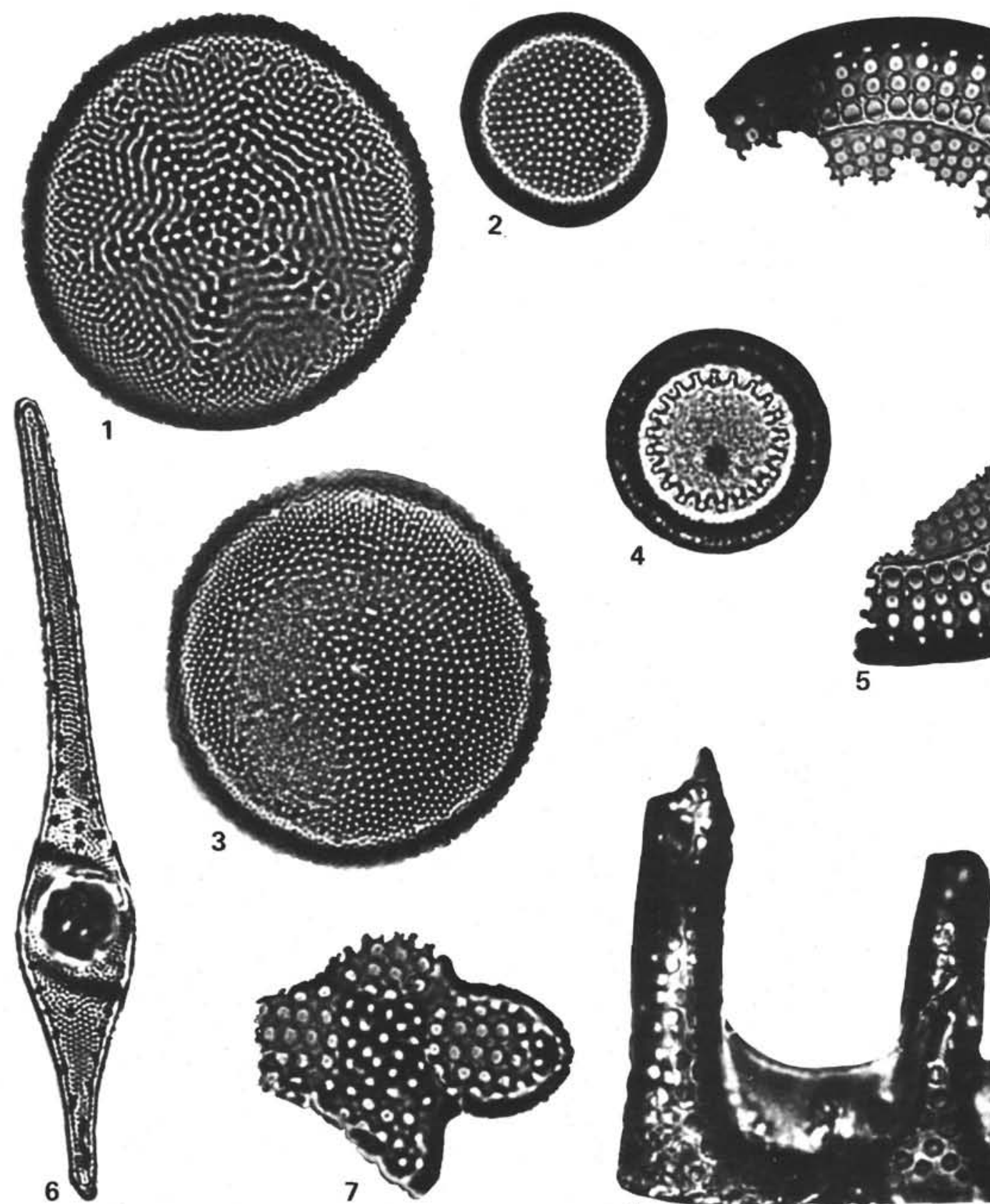